\title{
SURFICIAL GEOLOGY OF THE DALTON HIGHWAY (ITKILLIK-SAGAVANIRKTOK RIVERS) AREA, SOUTHERN ARCTIC FOOTHILLS, ALASKA
}

by

Thomas D. Hamilton
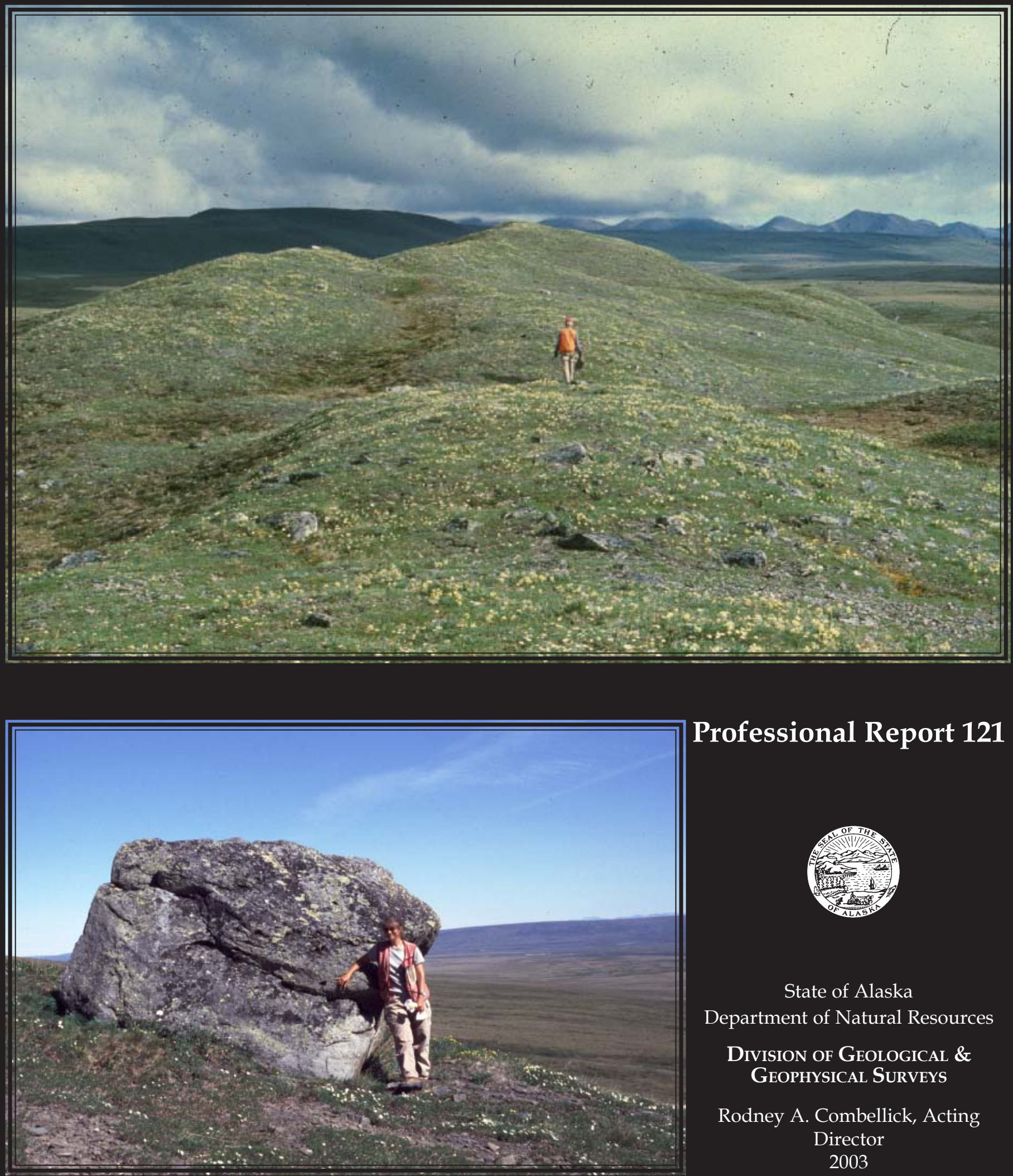

Professional Report 121

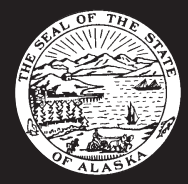

State of Alaska

Department of Natural Resources

Division of GeOlogical \& GEOPHYSICAL SURVEYS

Rodney A. Combellick, Acting Director 2003 
Front cover (top): Glacial deposits of Itkillik II age along west flank of Sagavanirktok River valley. Marked by narrow crests, steep flanking slopes, and discontinuous vegetation cover. Minor as well as major depositional features are well preserved.

Front cover (bottom): Large glacial erratic boulder on stabilized talus, east face of Slope Mountain.

Back cover: Airphoto mosaic of central part of map area between Toolik Lake (near north margin) and Galbraith Lake (south margin). Dalton Highway and Trans-Alaska Pipeline (white linear features) traverse image from south to north. Glacial deposits of late Pleistocene age form gravelly, lightly vegetated surfaces that appear as light gray tones on image. Older glacial deposits bear continuous vegetation, which appears red on image. 
PROFESSIONAL REPORT 121

\section{SURFICIAL GEOLOGY OF THE DALTON HIGHWAY (ITKILLIK-SAGAVANIRKTOK RIVERS) AREA, SOUTHERN ARCTIC FOOTHILLS, ALASKA}

by

Thomas D. Hamilton

2003

This DGGS Professional Report is a final report of scientific research. It has received technical review and may be cited as an agency publication. 


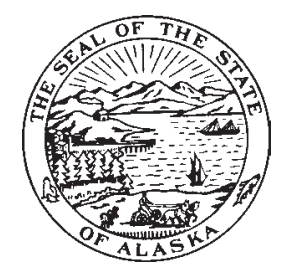

STATE OF ALASKA

Frank H. Murkowski, Governor

DEPARTMENT OF NATURAL RESOURCES

Tom Irwin, Commissioner

\title{
DIVISION OF GEOLOGICAL \& GEOPHYSICAL SURVEYS \\ Rod Combellick, Acting Director
}

DGGS publications may be inspected at the following locations. Address mail orders to the Fairbanks office.

\section{Alaska Division of Geological \\ \& Geophysical Surveys}

ATTN: Geologic Communications

794 University Avenue, Suite 200

Fairbanks, Alaska 99709-3645

Elmer E. Rasmuson Library

University of Alaska Fairbanks

Fairbanks, Alaska 99775-1005

\author{
University of Alaska Anchorage \\ Library \\ 3211 Providence Drive \\ Anchorage, Alaska 99508
}

Alaska Resource Library
3150 C Street, Suite 100
Anchorage, Alaska 99503

Alaska State Library

State Office Building, 8th Floor

333 Willoughby Avenue

Juneau, Alaska 99811-0571

\begin{abstract}
This publication was released by the Department of Natural Resources and the Department of Community and Economic Development, produced at a cost of $\$ 17.00$ per copy, and printed in Fairbanks, Alaska. Publication of this report is required by Alaska Statute 41 "to determine the potential of Alaska land for production of metals, minerals, fuels, and geothermal resources; the location and supplies of groundwater and construction materials; the potential geologic hazards to buildings, roads, bridges, and other installations and structures; and shall conduct such other surveys and investigations as will advance knowledge of the geology of Alaska."
\end{abstract}

NOTE: Mention of any company or brand name does not constitute endorsement by any branch or employee of the State of Alaska. 


\section{CONTENTS}

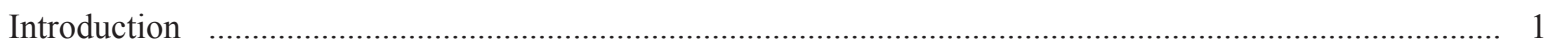

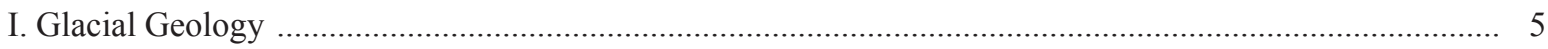

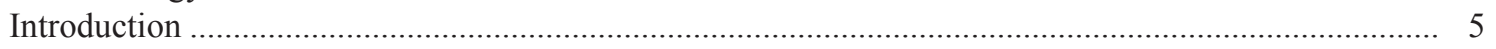

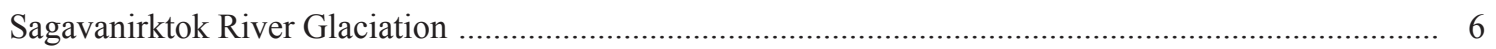

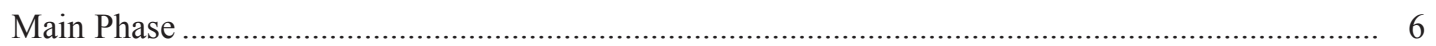

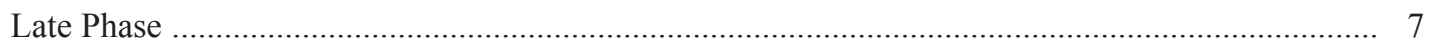

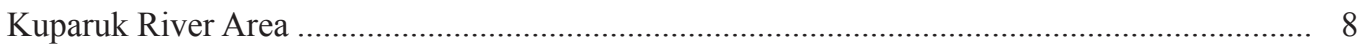

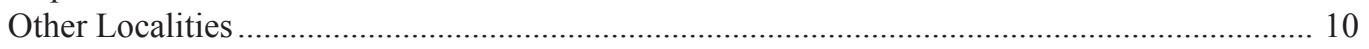

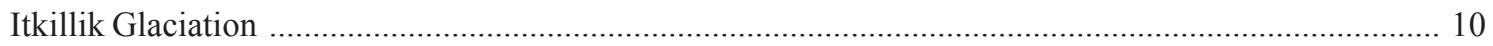

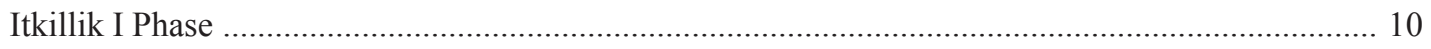

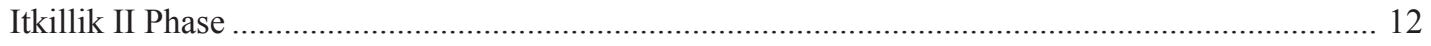

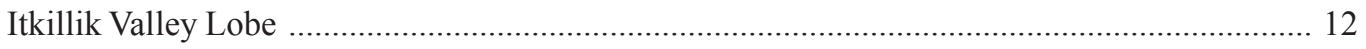

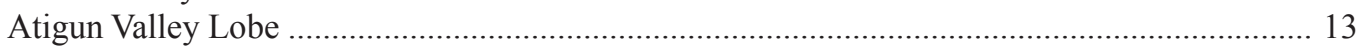

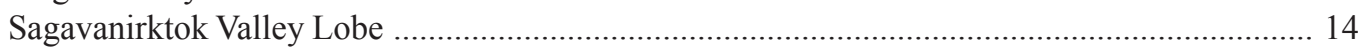

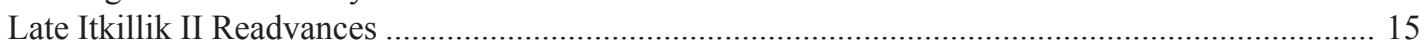

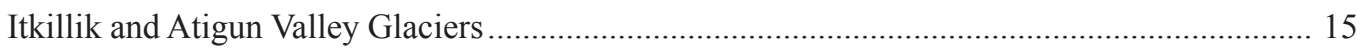

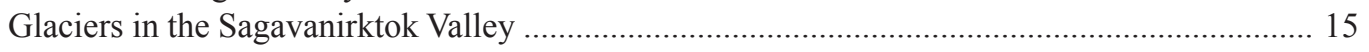

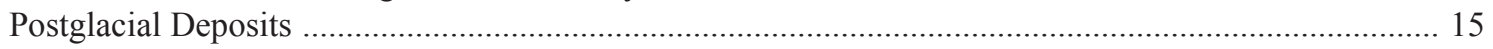

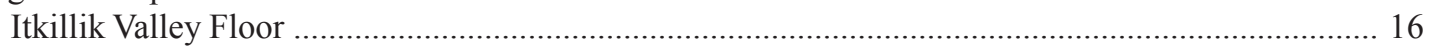

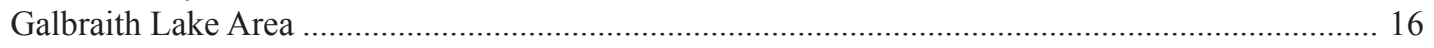

Lower Atigun River and Sagavanirktok Valley Floor .................................................................... 16

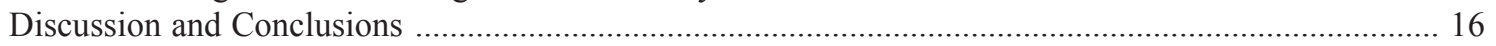

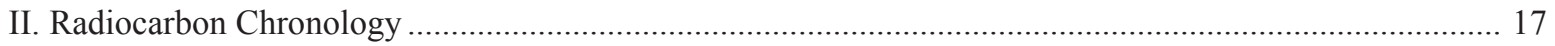

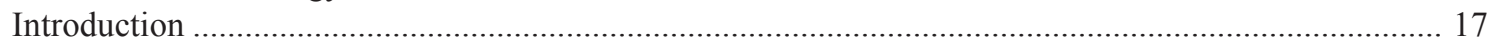

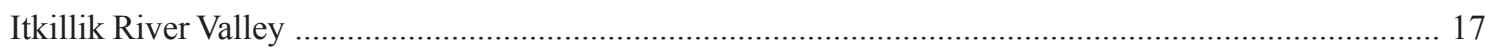

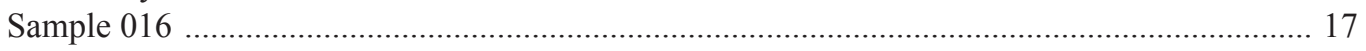

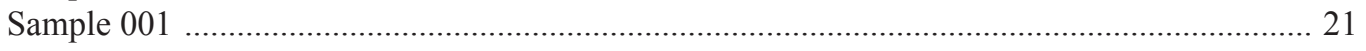

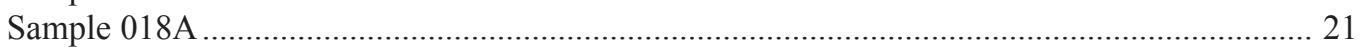

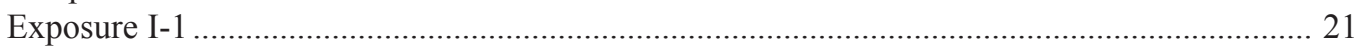

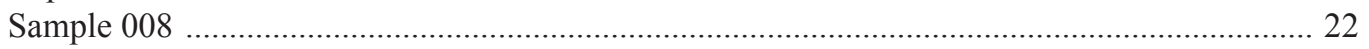

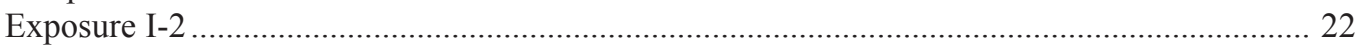

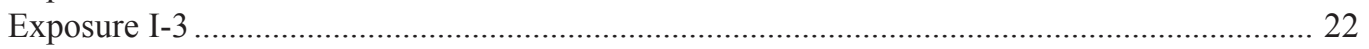

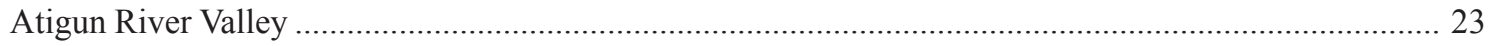

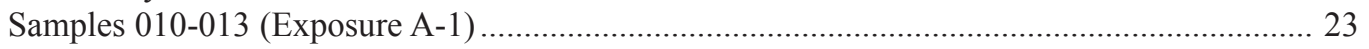

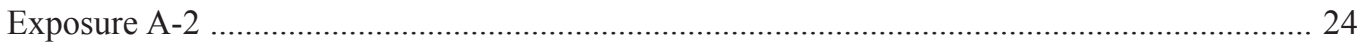

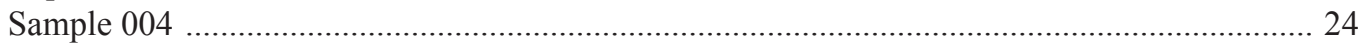

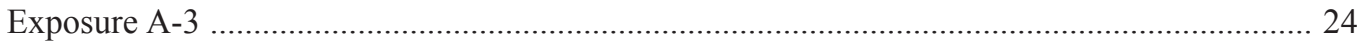

"Mosquito Lake" Test Pit (Kunz, 1977) ........................................................................................... 25

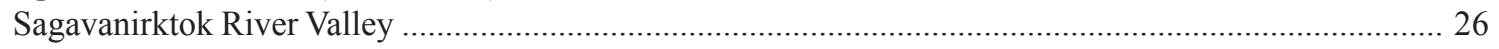

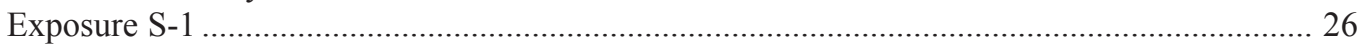

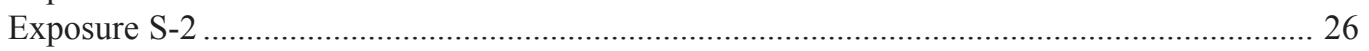

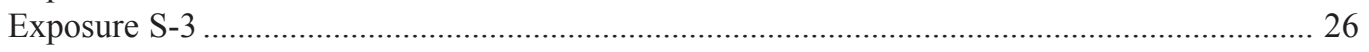

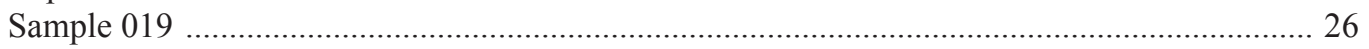

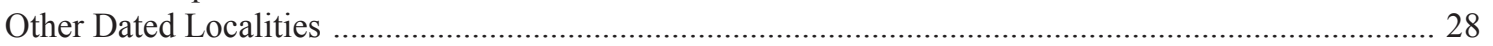

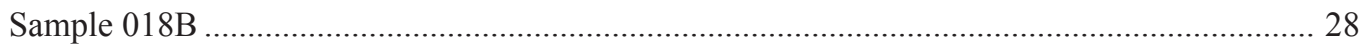

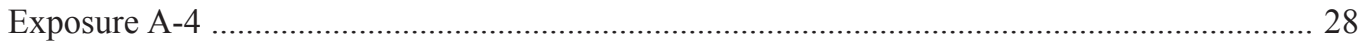

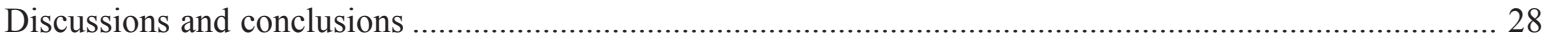

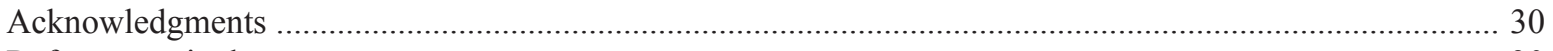

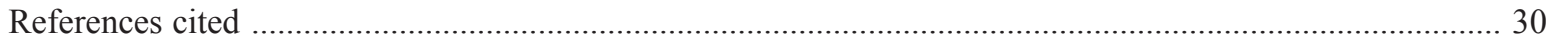




\section{FIGURES}

Figure 1. Map of Anaktuvuk-Sagavanirktok Rivers region near north flank of Brooks Range ................ 2

2. Generalized map of the glacial geology of the Itkillik-Sagavanirktok Rivers region ................. 3

3. Diagrammatic sketch showing how extent of successive drift sheets reflects Quaternary drainage evolution in north-central Brooks Range ................................................................. 4

4. Map of distribution of drift of Sagavanirktok River main phase across map area ...................... 7

5. Map of distribution of drift of Sagavanirktok River late phases across map area ..................... 9

6. Map of distribution of drift and outwash of Itkillik I glaciation ................................................ 11

7. Map of distribution of drift and outwash of Itkillik II glaciation .............................................. 13

8. Map of distribution of drift and outwash of late Itkillik II readvances ....................................... 14

9. Stratigraphic sections of Itkillik valley bluff and bank deposits ................................................ 20

10. Stratigraphic section of exposure I-1, north end of unnamed lake at south margin of

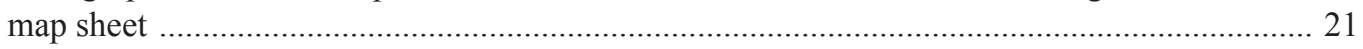

11. Stratigraphic section of exposure I-3, west side Itkillik River $2.1 \mathrm{~km}$ south of mouth of

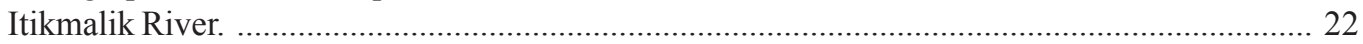

12. Stratigraphic section of exposure on east bank Atigun River $4.1 \mathrm{~km}$ beyond south margin

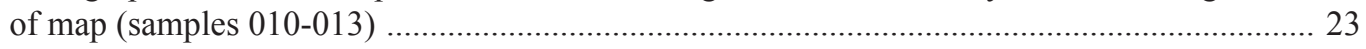

13. Stratigraphic section of exposure A-2, east side Atigun River $2.5 \mathrm{~km}$ south of

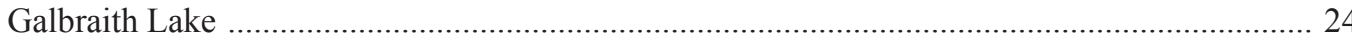

14. Stratigraphic section of bluff exposure along north side of Galbraith Lake outlet stream

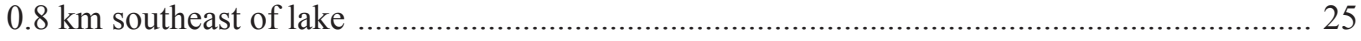

15. Stratigraphic section of exposure A-3, north bank Atigun River $0.5 \mathrm{~km}$ downstream (east) from mouth of Galbraith Lake outlet stream .............................................................. 25

16. Stratigraphic sections of bluff exposures with radiocarbon-dated deposits of late Itkillik II age, upper Sagavanirktok River valley ................................................................................ 27

17. Stratigraphic section of exposure S-3, west side Sagavanirktok River 6 km above mouth

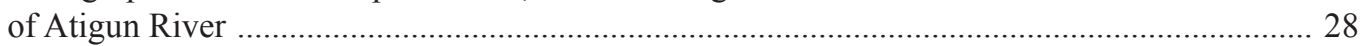

18. Stratigraphic section of bank exposure on west side of Sagavanirktok River $31 \mathrm{~km}$ north of

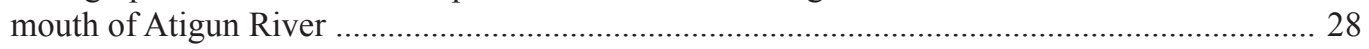

19. Stratigraphic section of bank exposure on northeast shore of small thaw pond on floor of pass across Imnavait Mountain 14 km north-northeast of Toolik Lake ....................................... 29

20. Stratigraphic section of exposure A-4. Headwall of active earthflow $4.5 \mathrm{~km}$ northwest of Galbraith Lake

\section{TABLES}

Table 1. Glacial sequence in the central Brooks Range showing correlations with drift units recognized in map area

2. Characteristics of drift of Sagavanirktok River, Itkillik I, and Itkillik II age, Itkillik valley region

3. Selected radiocarbon data, Itkillik River-Sagavanirktok River area 18

\section{SHEET \\ (in envelope)}

Sheet 1. Surficial geologic map of the Dalton Highway (Itkillik-Sagavanirktok Rivers) area, southern Arctic foothills, Alaska 


\title{
SURFICIAL GEOLOGY OF THE DALTON HIGHWAY (ITKILLIK-SAGAVANIRKTOK RIVERS) AREA, SOUTHERN ARCTIC FOOTHILLS, ALASKA
}

\author{
by
}

Thomas D. Hamilton ${ }^{1}$

\begin{abstract}
During middle and late Pleistocene time, the Itkillik-Sagavanirktok rivers area was glaciated repeatedly by ice that flowed north through deep bedrock troughs and terminated beyond the north flank of the Brooks Range. Eight individual glacial advances are recognized in the map area: Two are assigned to the Sagavanirktok River glaciation of middle Pleistocene age and six to the late Pleistocene Itkillik glaciation.

During the main phase of Sagavanirktok River glaciation, valley glaciers flowed north across the map area and terminated 20$25 \mathrm{~km}$ beyond its north margin. Glaciers in the Itkillik and Sagavanirktok valleys probably were fed by drainage networks resembling those of today, but the strongly glaciated Kuparuk valley floor has subsequently been elevated by tectonism into an upland surface that no longer is connected to its presumed source area in the bedrock valley of Atigun River. The late phase of Sagavanirktok River glaciation, which may include two or more events, followed a long interval of postglacial landscape modification. It was much less extensive than the main phase. Ice flowed through the valleys of the Itkillik and Sagavanirktok rivers, but it only lapped against the flanks of the plateau-like upper Kuparuk drainage.
\end{abstract}

The Itkillik glaciation is a complex of glacial advances that probably followed the maximum substage (marine-isotope substage 5e) of the last interglaciation. The Itkillik I phase, which is older than the range of radiocarbon dating, consisted of two advances (Itkillik IA and IB) that may have been separated by a considerable time period. At this time, the Atigun valley glacier had become considerably smaller than the Itkillik valley glacier to the west and the Sagavanirktok valley glacier to the east. The upper Atigun valley had probably been pirated of much of its drainage by westward extension of the head of the Sagavanirktok drainage system during middle Pleistocene time.

Glacier advances of Itkillik II age are radiocarbon dated between about 25 and $11.5 \mathrm{ka}$ (thousand radiocarbon yr B.P.). Their deposits are considerably less modified than those of the Itkillik I advances - slope angles are steeper, moraine crests narrower, soils and weathering features less developed, and kettles less modified. Two nested moraines generally mark the maximum advance of Itkillik II glaciers, and a late Itkillik II readvance also typically formed paired end moraines. As glaciers retreated into the Brooks Range at the close of the Pleistocene, sandy basin-filling deposits formed behind moraine dams in all major river valleys.

Thirty-three radiocarbon ages provide a partial chronology for latest Pleistocene and Holocene events within the map area and its immediate surroundings. The late Itkillik II readvance is dated at about $12.8-11.4 \mathrm{ka}$ at its type locality beyond the east end of Atigun Gorge. Unique episodes of rapid alluviation that occurred in Atigun valley about 5.0-5.4 ka and probably again about 2.0 ka might have been due to rapid base-level rise resulting from landsliding in Atigun Gorge. Peat beds at four widely spaced localities have radiocarbon ages between about 2.9 and $2.2 \mathrm{ka}$. This interval may represent an episode of milder climate when cirque glaciers were in retracted positions. Later intervals of peat formation near and below modern river level, dated at about 1.3 and $0.4 \mathrm{ka}$ in the cirque-fed upper valley of Itkillik River, may represent times of glacier shrinkage and decreased sediment yield.

Kettles with deep-seated, actively collapsing margins occur within drift of Itkillik II age. These features probably are underlain by relict glacier ice that continues to melt out at the present day, creating a significant hazard for engineering structures.

\section{INTRODUCTION}

The area covered by this map and report extends eastward from the Itkillik River valley across the Atigun and Kuparuk drainage systems into the western edge of the Sagavanirktok River valley (fig. 1). From its south margin near the north flank of the Brooks Range, the map area extends northward into the southern Arctic Foothills to a prominent outcrop belt of Cretaceous conglomerate, sandstone, and shale that forms Itigaknit, Imnavait, and Slope mountains (Brosgé and others, 1979).

The Dalton Highway, which traverses the map area, provides ready access to many localities of unusual in-

\footnotetext{
${ }^{1}$ Geologist Emeritus, U.S. Geological Survey, 4200 University Drive, Anchorage, Alaska 99508
} 


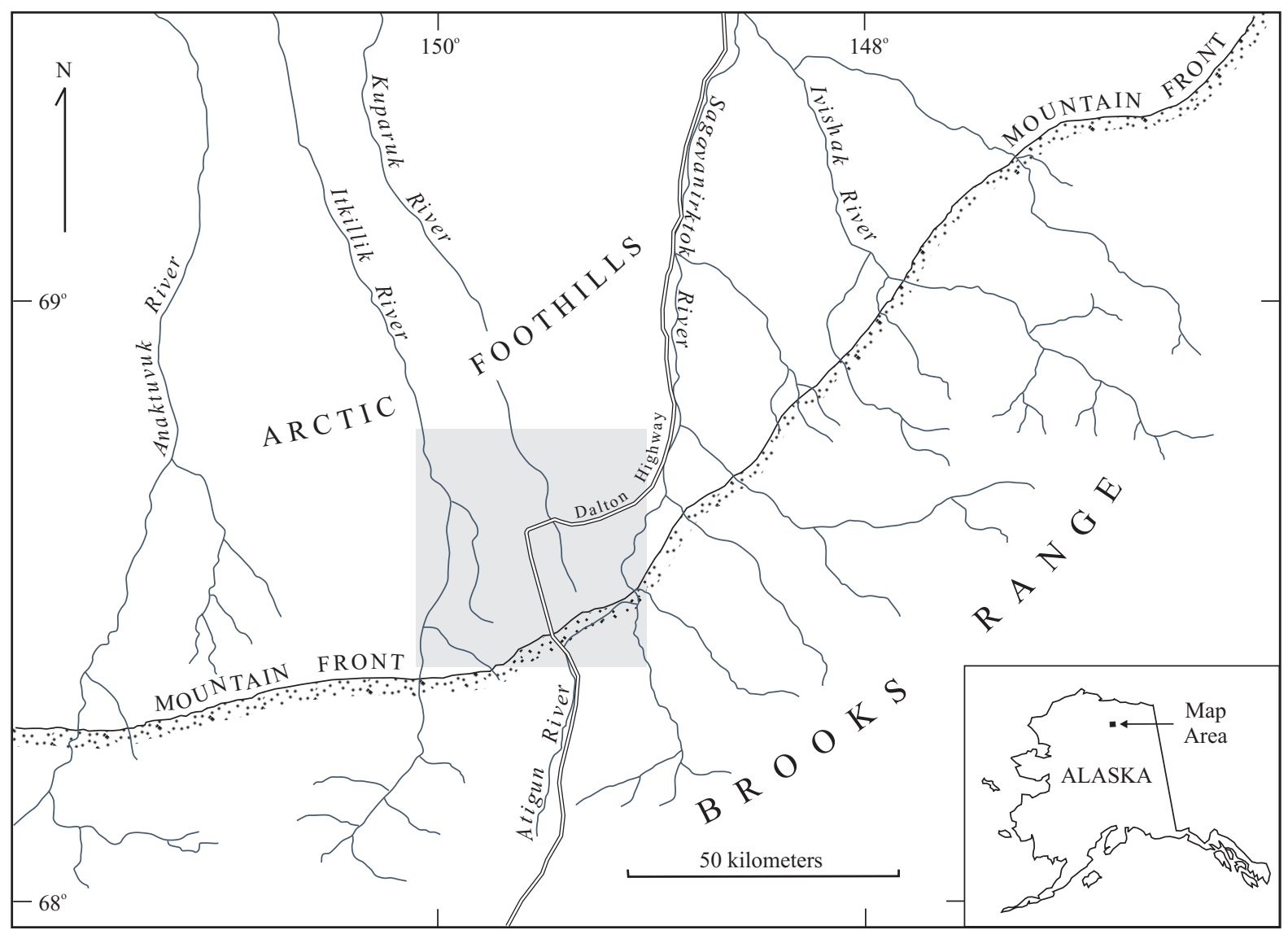

Figure 1. Anaktuvuk-Sagavanirktok rivers region near north flank of Brooks Range. Note change in trend of range front near map area (shaded area). Asymmetric pattern of Sagavanirktok drainage system contrasts with more symmetric drainages farther west.

terest. The highway itself, with its associated borrow pits, bridges, and culverts, provides excellent case studies of interactions between engineering structures and permafrost. The Toolik Field Station, operated by the University of Alaska for the National Science Foundation, is situated at Toolik Lake near the center of the map area. The Station's labs, offices, and experimental sites have largely been used for biologic investigations but would serve as an excellent base for geologic studies as well. The map area and its immediate surroundings provide classic examples of glacial geology, including the type localities of the Itkillik and Sagavanirktok River glaciations, two of the four major Pleistocene glacial advances defined by Detterman (1953; Detterman and others, 1958) for the Brooks Range. Also, as reviewed by Hamilton and Goebel (1999), the Sagavanirktok River valley within and adjoining the map area contains several archeological sites with substantial time depth. The Gallagher Flint Station (Dixon, 1975; Ferguson, 1997), the Hilltop site (Reanier, 1995), and the Putu-Bedwell site (Alexander, 1987; Reanier, 1995) have radiocarbon ages ranging back to about 10,500 yr B.P. Numerous younger archeological sites also have been recorded around lakes near the study area's south margin (for example, Kunz, 1977). Finally, as discussed in more detail below, the map area is situated at the boundary between the tectonically stable central Brooks Range and the still-active eastern Brooks Range. This facilitates direct comparison of the effects of Quaternary tectonism versus climatic changes alone on glaciation, drainage networks, valley evolution, and other aspects of landscape development.

Deposits created by glacial advances of middle and late Pleistocene age dominate the surficial geology of this area (fig. 2; sheet 1). Their complex map pattern reflects (1) interactions of glaciers that flowed northward through three principal mountain valleys, (2) repeated advances and retreats of those glaciers, (3) tectonism in the eastern part of the map area, and (4) the formation of permafrost within the glacial deposits. Pleistocene glaciers flowed into the map area via the Itkillik, Atigun, and Sagavanirktok River valleys. They were confined by deep bedrock troughs 


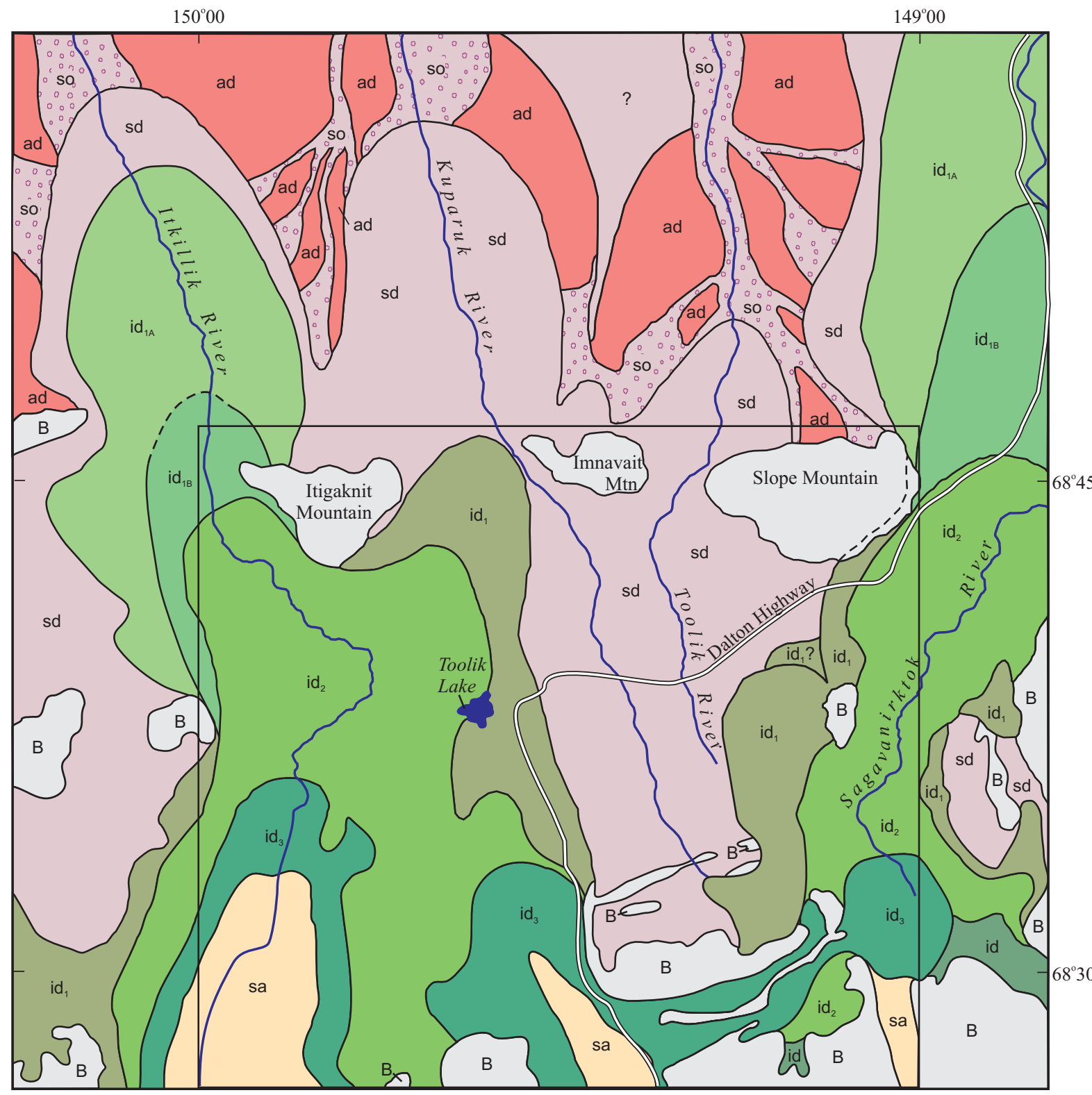

\section{Glacial deposits}

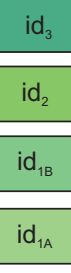

Drift of Itkillik II phase

Drift of Itkillik I phase, later advance

Drift of Itkillik I phase, maximum advance

Drift of Itkillik I phase, undifferentiated glaciation
Drift of Itkillik II readvance

Drift of Sagavanirktok River glaciation, undifferentiated

Outwash of Sagavanirktok River

Drift of Anaktuvuk River glaciation, undifferentiated

\section{Nonglacial deposits}

20 kilometers

Sandy basin-filling deposits

Bedrock

\section{Symbols}

_ - - Contact. Dashed where approximate.

Figure 2. Generalized map of the glacial geology of the Itkillik-Sagavanirktok rivers region. Note contrast between nested drift sheets of Itkillik River valley and less regular drift distributions farther east. Area of detailed map (sheet 1) outlined in black. 
within the Brooks Range, but ice and meltwater were less constricted beyond the north flank of the mountains and were able to flow laterally into neighboring valley systems.

Eight individual glacial advances, two of middle Pleistocene age and six during the late Pleistocene, are recognized in the map area. The pattern of each advance tended to differ from the one preceding it because of blockage by previously deposited moraines and because of glacial piracies and ongoing tectonism. The relative extent of successive drift sheets in neighboring valleys of the north-central Brooks Range reflects the relative volumes of alpine glaciers, and thereby provides a measure of drainage changes with time (figs. 2, 3). This pattern indicates that the principal north-trending valleys, such as the Anaktuvuk and Sagavanirktok, which are spaced regularly at intervals of about $100 \mathrm{~km}$, progressively pirated their neighboring drainages to become dominant during the course of the Quaternary. The intervening glacial valleys, which initially supported large glaciers, progressively lost glacial discharge as their headwaters were captured by the master valleys and therefore supported only small glaciers during late Quaternary time.

The map area is situated at the boundary between the central Brooks Range, which had become tectoni- cally stable by late Cenozoic time, and the eastern Brooks Range, which continued to be tectonically active through the Quaternary (Grantz and others, 1994). During each late Cenozoic glacial episode, alpine glaciers of the north-central Brooks Range reoccupied their deep bedrock valleys and flowed north from the range front between pairs of massive compound lateral moraines, which stand as high as $300 \mathrm{~m}$ along the flanks of the principal glacial valleys (for example, Hamilton, 1979a, 1980). Because of the thick, continuous permafrost that underlies this region, the moraines must have been nearly as resistant as bedrock, and younger glacial advances seldom breached them. In contrast, the eastern Brooks Range has been subjected to northwardverging thrust faulting and associated detachment faulting that continued through the Quaternary up to the present day (Grantz and others, 1994). The drainage patterns of this region consequently are less regular, and drainage history is more complex. Eastward across the map area, the range front abruptly changes to a northeasterly trend (fig. 1). The strongly asymmetric Sagavanirktok drainage system, which is dominated by its eastern tributaries, contrasts markedly with the more regular drainage networks farther west. Its glacial history, as recorded by drift sheets of differing ages, also shows less regularity (Hamilton, 1986).

Figure 3. Diagrammatic sketch showing how extent of successive drift sheets reflects Quaternary drainage evolution in northcentral Brooks Range. Two master valleys have progressively captured drainage from intervening valley system by headward erosion of tributaries along east-weststriking belts of erodible rock. The three valleys supported glaciers of comparable size during early Pleistocene time, but by the late Pleistocene the middle valley was reduced to a relatively small glacial drainage network (dashed line designates its former length). Based on drift distributions mapped along north flank of Brooks Range (Hamilton, 1978, 1979a, 1980).

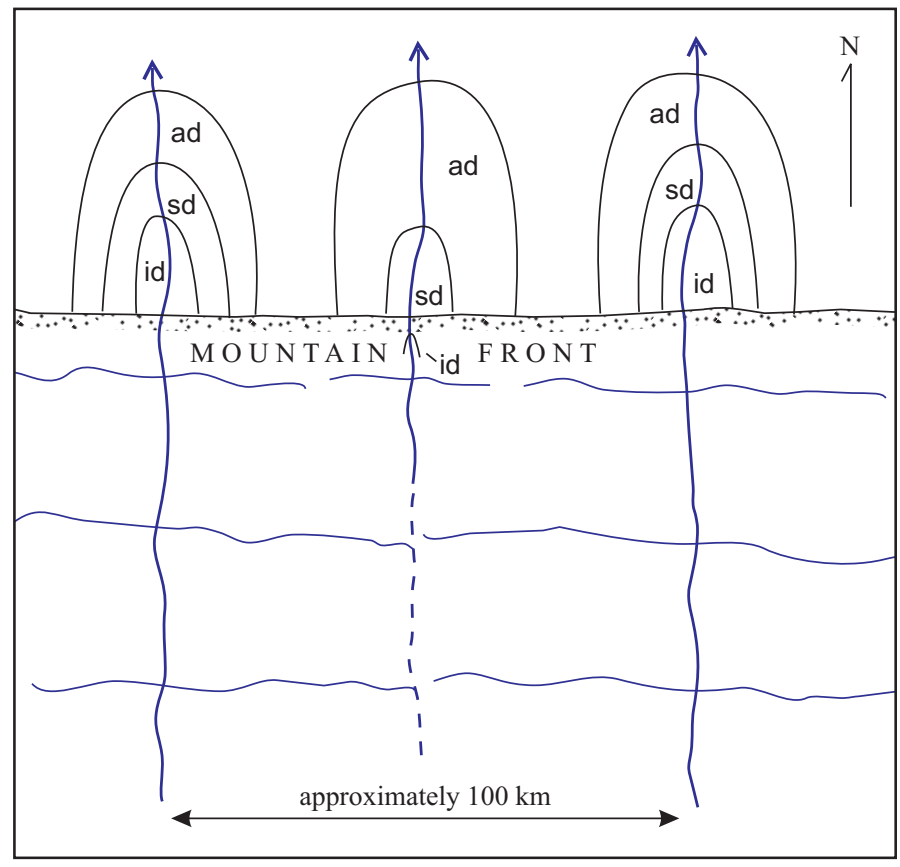

DRIFT COMPLEXES

id Drift of Itkillik (late Pleistocene) age

sd Drift of Sagavanirktok River (middle Pleistocene) age

ad Drift of Anaktuvuk River (early Pleistocene) age 
On a smaller scale, some of the complex surficial geology of the map area is due to the influence of permafrost, which underlies an active layer of variable thickness that freezes and thaws annually. The active layer ranges in thickness from 25 to $30 \mathrm{~cm}$ in poorly drained deposits beneath thick moss and sod cover to as much as a meter in permeable, coarse-grained sediments (Munroe and Bockheim, 2001). Permafrost occurs at greater depth beneath water bodies, and may lie several tens of meters beneath the largest, deepest lakes of the map area and beneath deep channel segments of the Itkillik and Sagavanirktok rivers. Although exact thickness of the permafrost is uncertain, records from other parts of the northern Brooks Range and Arctic Foothills (for example, Ferrians, 1965; Brown and others, 1997) suggest that its base probably occurs at about $150-250 \mathrm{~m}$ depth.

Glacier ice stagnating and wasting away at the close of the Pleistocene may have been preserved as "permafrost" under some circumstances. Glaciers with ice exposed at the surface or covered by only a thin debris layer would have continued to downwaste. As the ice thinned, however, its debris load would tend to accumulate and thicken at the surface, and the rate of downwasting consequently would decrease. Thick debris cover would allow relict glacier ice to persist beneath an active layer that thaws each summer, and thus become part of the local permafrost. One indication of persisting subsurface glacier ice is kettle lakes that continue to enlarge today (Hamilton, 1982a). Such kettles have unvegetated, unstable flanks that steepen downward to near vertical at water level or that are subject to extensive slump and flowage. Their water generally is turbid owing to abundant fine mineral sediment held in suspension. Six kettles of this type have been identified on drift of late Pleistocene age within the map area (unit $\mathbf{i k}_{\mathrm{a}}$ on sheet 1), and several others occur on the west flank of Itkillik River valley just beyond the northwest corner of the map.

Near-surface permafrost also promotes solifluction, the slow flowage of soil within the active layer during the annual thaw season. Solifluction is widespread in the map area, and is most active during spring and early summer when the active layer generally is saturated with moisture released by thawing that remains confined above the surface of impermeable permafrost. Movement rates up to $5 \mathrm{~cm} / \mathrm{yr}$ are common, but more rapid rates up to 10 or even $15 \mathrm{~cm} / \mathrm{yr}$ have been recorded on some solifluction slopes (Washburn, 1980, p. 208-213). Solifluction is widespread on older glacial deposits, which it tends to modify or obscure.

The following text is divided into two principal sections. The first section is a discussion of the glacial geology of the map area, particularly the distributions and distinguishing characteristics of the individual drift units present. The second section is focused on the radiocarbon chronology of the map area together with the stratigraphic sections on which it is based. The radiocarbon record mostly pertains to Holocene events, and it covers only the youngest advance of the Pleistocene glacial succession.

\section{GLACIAL GEOLOGY INTRODUCTION}

The basic glacial sequence for the central Brooks Range was defined by Detterman and others (1958), with modifications by Porter (1964), Hamilton and Porter (1975), and Hamilton (1986). Current nomenclature is summarized in table 1. Drift of four major glacial intervals is recognized in the valleys of the Itkillik and Sagavanirktok rivers (Hamilton, 1978, 1979a); and these valleys are the type localities for two of the glaciations (Detterman, 1953). The oldest two advances, the Gunsight Mountain and Anaktuvuk River glaciations, are inferred to date from late Tertiary and early Pleistocene time, respectively (Hamilton, 1986, 1994). Drift sheets assignable to these glaciations are widespread north of the Brooks Range (fig. 2), but near the range front they have been overlapped and obliterated by younger glacial advances or eroded from steep slopes. Neither drift is recognized within the map area. The next younger glacial advance, the Sagavanirktok River glaciation, is believed to be a complex of glacial events dating broadly from middle Quaternary time (about 780,000 to 125,000 yr B.P.). Within the map area, drift of Sagavanirktok River age forms two principal units that contrast in postglacial modification and probably were separated by one or more major interglaciations.

The youngest Pleistocene glacial advances were included within the Itkillik glaciation by Hamilton and Porter (1975), who subdivided this sequence into Itkillik I and Itkillik II advances. Two glacial advances of Itkillik I age and two during Itkillik II time are currently recognized in the Brooks Range (Hamilton, 1986, 1994). Itkillik I advances occurred more than $53 \mathrm{ka}$ (thousand radiocarbon yr B.P.). They are believed to be younger than the last interglacial maximum (isotope stage 5e), although this interpretation has been considered controversial (Hamilton, 1994, p. 827-829). In some major valleys, Itkillik I drift sheets are divisible into two subunits (termed IA and IB) that contrast in postglacial modification and therefore may differ significantly in age. Along the Itkillik and Sagavanirktok drainage systems, these subunits are recognized only north of the map area; however they also are present near the northcentral margin of the map. The subsequent Itkillik II advances occurred between about 25 and $11.5 \mathrm{ka}$, and 
Table 1. Glacial sequence in the central Brooks Range (after Hamilton, 1994) showing correlations with drift units recognized in map area

\begin{tabular}{|c|c|c|c|}
\hline Age & Glaciation & Phase & Map Unit \\
\hline Holocene & Neoglaciation & - & - \\
\hline \multirow{3}{*}{ Late Pleistocene } & \multirow[t]{2}{*}{ Itkillik II } & $\int$ Latest Itkillik II readvance & $\left\{\begin{array}{l}\mathrm{id}_{3 \mathrm{~B}} \\
\mathrm{id}_{3 \mathrm{~A}}\end{array}\right.$ \\
\hline & & Main advance & $\left\{\begin{array}{l}\mathrm{id}_{2 \mathrm{~B}} \\
\mathrm{id}_{2 \mathrm{~A}}\end{array}\right.$ \\
\hline & Itkillik I & $\left\{\begin{array}{l}\text { Phase B } \\
\text { Phase A }\end{array}\right.$ & $\begin{array}{l}\mathrm{id}_{1 \mathrm{~B}} \\
\mathrm{id}_{1 \mathrm{~A}}\end{array}$ \\
\hline Middle Pleistocene & Sagavanirktok River & $\left\{\begin{array}{l}\text { Late Phase } \\
\text { Main Phase }\end{array}\right.$ & $\begin{array}{l}\mathrm{sd}_{2} \\
\mathrm{sd}\end{array}$ \\
\hline Early Pleistocene & Anaktuvuk River & - & - \\
\hline Late Tertiary & Gunsight Mountain & - & - \\
\hline
\end{tabular}

are broadly contemporaneous with the major late Wisconsin glaciation of the standard North American glacial succession (Richmond and Fullerton, 1986; Hamilton, 1994). A late Itkillik II readvance is recorded in many valleys of the central Brooks Range (Hamilton, 1986, p. 37-38); it is recognized as a 2-fold event in Itkillik River valley and north of Galbraith Lake, and is bracketed by radiocarbon dates of about 12.8 and $11.4 \mathrm{ka}$ near the east end of Atigun Gorge (see Radiocarbon Chronology).

Late Holocene glacial deposits, assigned to the Neoglacial interval of Porter and Denton (1967), are common at altitudes above about 1,500 $\mathrm{m}$ in Brooks Range cirques and valley heads (for example, Ellis and Calkin, 1984). Although the Neoglacial ice advances took place farther south, they probably caused alluviation through upper parts of several cirque-headed valley systems that extended northward into the map area (Hamilton, 1981).

\section{SAGAVANIRKTOK RIVER GLACIATION Main Phase}

During Sagavanirktok River time, large valley glaciers flowed north along the Itkillik, Kuparuk, and Sagavanirktok drainages to outer limits about 20-25 km beyond the north margin of the map. The Itkillik and Sagavanirktok lobes probably were fed by drainage networks much like those of today, but the source of the Kuparuk lobe is obscure. The Kuparuk glacier was nearly as large as that in the Itkillik valley, judging from the comparable sizes and northward extents of their drift sheets and the comparable sizes of their outwash trains. The Kuparuk glacier probably was fed by the Atigun River valley, and may reflect a time before that valley's head was captured by south-flowing drainage systems or its eastern tributaries were pirated by the upper Sagavanirktok River drainage.

Drift of the Sagavanirktok River main phase (unit sd) is widespread across the upland drained by the Kuparuk and Toolik rivers and along the north margin of the map (fig. 4). Elsewhere, it is overlapped by younger glacial deposits or obscured by solifluction sheets on the flanks of bedrock highlands. It is discontinuous to absent on many steep bedrock slopes owing to mass wastage and erosion.

The subdued drift landscapes of the Sagavanirktok River main phase reflect a long interval of postglacial modification. Moraines typically are entirely vegetated (Walker and Walker, 1996); they have broad crests and gentle flanking slopes (table 2). Crests and upper slopes have continuous cover of windblown silt (loess), but widely dispersed large erratic boulders protrude as much as $1 \mathrm{~m}$ above the silt. Solifluction has redistributed much of the loess cover from upper to lower parts of moraine flanks, and ubiquitous horsetail drainages and lack of stream channels indicate that solifluction is still active. Many of the swales between moraines contain thick deposits of ice-rich silt (unit si), within which small thaw ponds have developed. Kettle lakes are almost entirely absent, having been destroyed by erosion or 


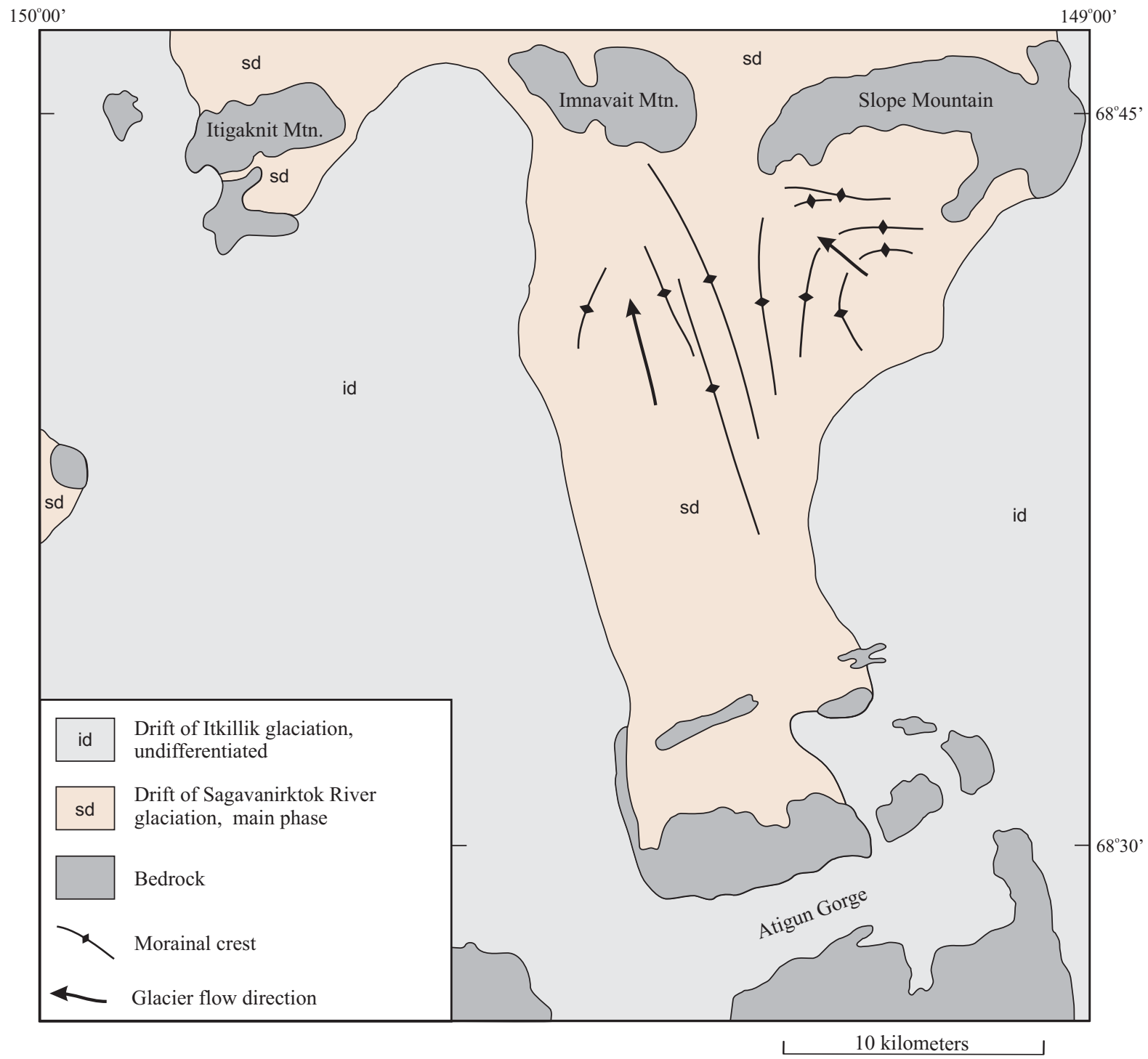

Figure 4. Distribution of drift of Sagavanirktok River main phase (colored) across map area. Light shading shows extent of subsequent overlap by glaciers during Itkillik time.

filled by solifluction debris and loess. Most drainages have silty channels with beaded thaw ponds along them. For example, the Kuparuk River meanders through a silty floodplain (unit al-sp) that contains numerous thaw ponds.

The smoothly arcuate moraines of Sagavanirktok River age, their nearly continuous crests, and their general occurrence as paired features indicate that they formed as lateral moraines and were subjected to only minor postglacial stream dissection. Their map pattern therefore delineates two separate lobes of glacier ice in the Kuparuk-Toolik River area. The western lobe, the larger of the two, may have been centered on presentday Kuparuk River, but its west margin is obscure. It probably was generated by a glacier that originated in
Atigun valley, but continued north wholly or in part across the now-elevated Kuparuk-Toolik upland. The eastern lobe was centered on the present-day unnamed east fork of Toolik River. This glacier probably flowed northwest after spilling over the west wall of Sagavanirktok valley and diverging from the larger glacier in that drainage system.

\section{Late Phase}

Glacial deposits of apparent age intermediate between that of the Sagavanirktok River and Itkillik drift (shown as units $\mathbf{s d}_{\mathbf{2}}$ and $\mathbf{s d}_{\mathbf{2}}$ ?) occur along Kuparuk River near its head and west of Kuparuk River just beyond the mapped outer limit of Itkillik drift (fig. 5). They also occur along the east fork of Toolik River and 
Table 2. Characteristics of drift of Sagavanirktok River, Itkillik I, and Itkillik II age, Itkillik valley region (from Hamilton, 1986)

\begin{tabular}{|c|c|c|c|c|c|c|}
\hline & \multirow{2}{*}{$\begin{array}{c}\text { Sagavanirktok River } \\
\begin{array}{c}\text { End } \\
\text { moraine }\end{array}\end{array}$} & \multicolumn{3}{|c|}{ Itkillik I } & \multicolumn{2}{|c|}{ Itkillik II } \\
\hline 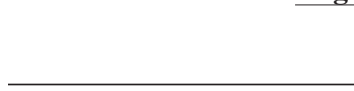 & & $\begin{array}{c}\text { End } \\
\text { moraine }\end{array}$ & $\begin{array}{c}\text { Lateral } \\
\text { moraine }\end{array}$ & $\begin{array}{c}\text { Kame } \\
\text { field }\end{array}$ & $\begin{array}{c}\text { End } \\
\text { moraine }\end{array}$ & $\begin{array}{c}\text { Kame } \\
\text { field }\end{array}$ \\
\hline \multicolumn{7}{|l|}{ MORPHOLOGY } \\
\hline Crest width (m) & $100-200$ & $5-10$ & $6-8$ & - & $4-5$ & 2 \\
\hline Maximum slope angle $\left({ }^{\circ}\right)$ & $2.5-3$ & 15 & 21 & 20 & 17 & 17.5 \\
\hline Irregularities per $200 \mathrm{~m}^{\mathrm{a}}$ & 0 & 7 & 6 & 17 & 8 & 8 \\
\hline \multicolumn{7}{|l|}{ WEATHERING } \\
\hline Boulders per $250 \mathrm{~m}^{2}$ & $1-5$ & 197 & - & $58^{\mathrm{b}}$ & 203 & $121^{\mathrm{b}}$ \\
\hline $\begin{array}{l}\text { Boulder protrusion } \\
\text { ( } \% \text { of diameter) }\end{array}$ & $5-20$ & 25 & 50 & 50 & $40-60$ & $>50$ \\
\hline Soil color, maximum & $10 Y R 4 / 4$ & $7.5 \mathrm{YR} 3 / 2$ & - & - & $10 Y R 4 / 3$ & 10YR 4/2 \\
\hline Weathering rinds (mm) & -- & $0.5-1.5$ & 0.4 & 1.3 & $0.5-1.0$ & $0.5-1.5$ \\
\hline \multicolumn{7}{|l|}{ CLAST LITHOLOGY \% } \\
\hline \multicolumn{7}{|l|}{ Kanayut Conglomerate } \\
\hline Conglomerate facies & 78 & 64 & 56 & 80 & 40 & 55 \\
\hline Sandstone facies & 15 & 33 & 25 & 20 & 35 & 40 \\
\hline Ferruginous sandstone & 7 & trace & 0 & 0 & 0 & 0 \\
\hline Nanushuk Formation & 0 & 2 & 15 & 0 & 16 & 5 \\
\hline Lisburne Group limestone & 0 & 1 & 4 & 0 & 9 & 0 \\
\hline \multicolumn{7}{|l|}{ VEGETATION } \\
\hline Cover $\%$ & 100 & -- & 50 & 85 & 80 & 80 \\
\hline Composition & ussock tundra & \multicolumn{3}{|c|}{ Mixed Tussock tundra and Dryas heath } & \multicolumn{2}{|c|}{ Dryas heath } \\
\hline
\end{tabular}

${ }^{a}$ Measured along moraine crest.

${ }^{b}$ Very stony surface, but most stones are smaller than boulder size.

at several other localities near the north margin of the map. These drift remnants appear to represent a much less extensive glacial advance that followed the main phase of the Sagavanirktok River glaciation after a long interval. Some of the deposits west of Kuparuk River (sd with diagonal overprint, sheet 1) may also date from this advance, but they more likely represent older drift that was rejuvenated by later glacial meltwater that stripped away insulating cover of sod and silt, selectively washed away finer sediment, and left behind lag deposits of bouldery gravel.

\section{Kuparuk River Area}

Closely spaced, slightly arcuate morainal ridges occur along the east side of Kuparuk River 9 to $13 \mathrm{~km}$ north of the northern flank of Atigun Gorge. Gravel terrace remnants, which may represent a former outwash train, originate near the northernmost ridge and extend northward along both sides of the river. The ridges have been largely obliterated by solifluction along the west side of Kuparuk River, but faint breaks in slope may mark their former positions. The ridges appear to define a glacial lobe that retreated southward, depositing a set of recessional moraines. These ridges and their outwash subsequently were eroded along the river, leaving concentrations of water-washed coarse gravel.

East of Kuparuk River, the moraines mapped as $\mathbf{s d}_{2}$ and $\mathbf{s d}_{\mathbf{2}}$ ? occupy the floor of a valley about $180-200 \mathrm{~m}$ deep and approximately $6 \mathrm{~km}$ wide that was eroded by the river within the drift sheet of the main phase of Sagavanirktok River glaciation following the retreat of that glacier. The late-phase moraines consequently are much younger than those of the main phase, and they probably formed during a separate glaciation. Because they extend beyond the mapped outer limits of Itkillik I glacier advances into the upper Kuparuk River valley, and probably were eroded by meltwater from that glacier lobe (see following section), they are older than the Itkillik I advance. Because of their extensive obliteration by solifluction, they are considered to be significantly older than Itkillik age, and they must represent a late-middle Pleistocene glaciation. Similar deposits have been mapped as "Drift of Younger Sagavanirktok River Age" farther west in the Brooks Range (for example, Hamilton, 1979a, 1980).

Drift intermediate in appearance between Sagavanirktok River and Itkillik deposits was deposited along the west flank of Kuparuk River valley, 


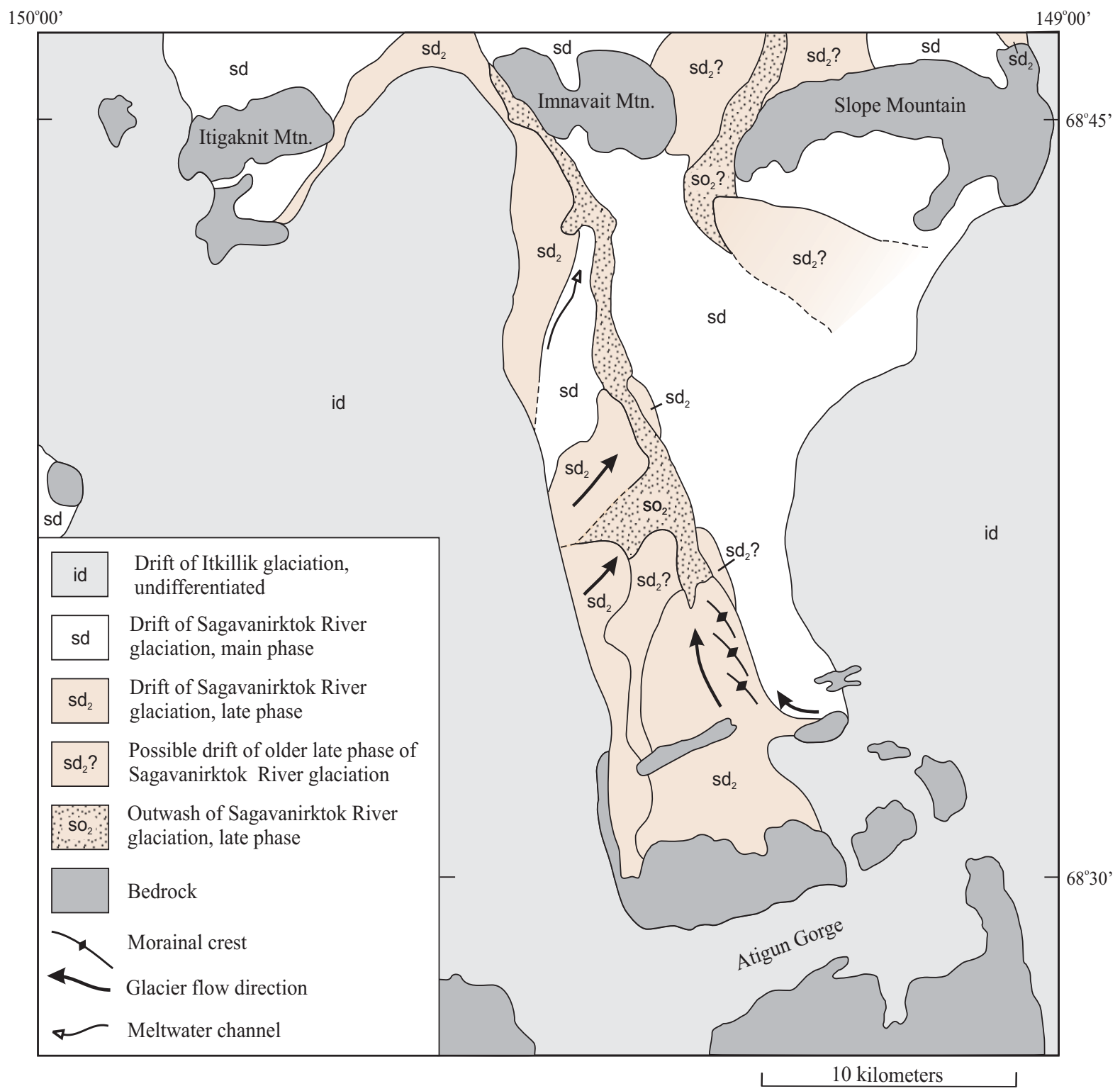

Figure 5. Distribution of drift of Sagavanirktok River late phases (colored) across map area. Drift of several phases probably is present, but only the youngest is clearly distinguishable. Light shading shows extent of subsequent overlap by glaciers during Itkillik time.

probably as spillovers from a large glacier in the lowland between present-day Galbraith and Toolik lakes. These deposits (unit $\mathbf{s d}_{\mathbf{2}}$ ) lack the broad sweeping moraines, smooth flanking solifluction slopes, and broad silt-filled depressions that are typical of Sagavanirktokage deposits. Kettles are present, but these are more widely scattered and more modified by solifluction than typical kettles of Itkillik age. The individual deposits probably represent lobes of glacier ice that flowed eastward across the Kuparuk drainage divide. Alternatively, some of the kettles and irregular relief might have formed when meltwater streams of Itkillik age eroded insulating vegetation, sod, and sediments that overlay relict glacier ice that had persisted from older advances of Sagavanirktok River age.

Possible older glacial deposits of late Sagavanirktok River age (shown as $\mathbf{s d}_{2}$ ?) occur beyond well-defined drift lobes in upper Kuparuk valley and along its west flank. These deposits are concordant in form and appearance with the drift lobes of late Sagavanirktok River age and share the same valley system that was deeply eroded into drift of the Sagavanirktok River main advance. They may represent an older phase of late Sagavanirktok River glaciation. 


\section{OTHER LOCALITIES}

Deposits of late phase advances of the Sagavanirktok River glaciation occur within and near the broad gap between Itigaknit and Imnavait mountains. These drift remnants appear to be paired segments of an end-moraine complex deposited during an ice advance slightly more extensive than the outermost advance of Itkillik age. The drift probably was deposited by a northeast-flowing lobe of the Itkillik valley glacier that was confluent with north-flowing ice from Atigun River valley.

Deposits of similar age may also be present along Toolik River's east fork. This drift defines a northwestflowing overflow lobe from Sagavanirktok River valley that generated an outwash train that extends beyond the north margin of the map. About $3.5 \mathrm{~km}$ north of the map's edge, older drift remnants coalesce into a welldefined end moraine-outwash train complex that resembles drift of late Sagavanirktok River age and could represent an older advance of that glacial interval.

A small area of drift of late Sagavanirktok River age also occurs at the extreme northeast corner of the map area. This deposit extends northward into a more continuous body of drift with a well-defined outer limit that forms part of the compound lateral moraine along the west flank of Sagavanirktok River valley (see fig. 2).

\section{ITKILLIK GLACIATION}

The Itkillik glaciation is broadly equated with late Pleistocene ice advances that followed the maximum substage (marine isotope substage 5e) of the last interglaciation (Hamilton, 1986, 1994). Two major phases are recognized. The Itkillik I phase is older than the range of radiocarbon dating and consists of two advances (Itkillik IA and Itkillik IB) that may be widely separated in age. The Itkillik II phase, which is radiocarbon dated at between 25 and $11.5 \mathrm{ka}$, consists of an initial main advance and a later readvance that is dated at about 12.8-11.9 ka (Hamilton, 1986). Detailed mapping in the Itkillik valley and between Galbraith and Toolik lakes has shown that double sets of moraines were deposited during both the principal Itkillik II advance and the late Itkillik II readvance (sheet 1).

\section{Itkillik I Phase}

During the maximum recognized advance of the Itkillik glaciation, valley glaciers in the Brooks Range flowed north through the deep bedrock troughs now occupied by the Itkillik, Atigun, and Sagavanirktok rivers. Beyond the range front, glacial lobes in the Itkillik and Sagavanirktok valleys were of similar widths and they extended comparable distances beyond the mouths of their mountain valleys. The glacier that flowed north from Atigun valley was significantly smaller than its neighbors, and it extended only $27 \mathrm{~km}$ north of the range front. For much of this distance, its west margin may have coalesced with the Itkillik valley glacier.

Postglacial weathering and erosion have modified the irregular drift of Itkillik I age much less than the smoother Sagavanirktok-age moraines (table 2), but postglacial modification is present on a smaller scale. Moraine crests are 5-10 m wide, and they typically are slightly flattened; their surfaces commonly bear frost hummocks, frost boils, and secondary and tertiary polygons as described by Black (1976, p. 6-7). Erratic boulders are more abundant than on the surface of older drift. Many boulders have disintegrated down to ground level, but others protrude by as much as half of their diameters. Rock types preserved on the moraines are more diverse than on the older glacial deposits. Vegetation cover is less continuous and more variable than on moraines of Sagavanirktok River age (Jorgenson, 1984; Walker and Walker, 1996), and topographic crests typically have discontinuous cover of heath plants interspersed with patches of bare gravel and shattered boulder fragments. Lower slopes and swales are covered with silty solifluction deposits, but they lack the thick accumulations of ice-rich silt that are present on older glacial deposits.

Drainage features also differ markedly from those of Sagavanirktok River age. Kettles generally are present. They are subrounded to subangular in outline, with grassy flanks and marshy shores that have developed on accreting aprons of soliflucted silt. Most kettles are connected by small streams. Drainage networks are well integrated, but they remain largely controlled by primary drift morphology and original glacial drainage patterns. For example, arcuate stream courses occupy depressions between lateral moraines, and other streams flow outward from drift margins along channels carved by former meltwater drainage.

Glaciers of Itkillik I age in the Itkillik and Sagavanirktok valleys extended well beyond the north margin of the map, and most of their deposits within the map area were overridden and obliterated by subsequent advances of Itkillik Phase II glaciers (fig. 6). More extensive deposits are exposed beyond the limits of Itkillik II drift in the central and north-central parts of the map. Paired arcuate lateral moraines outline a north-flowing ice tongue that terminated about $15 \mathrm{~km}$ north of present-day Toolik Lake in the gap between Itigaknit and Imnavait mountains. The east margin of this glacier extended north along the western edge of the upland now occupied by Kuparuk and Toolik rivers. Its outer limit is poorly defined on the steep bedrock slopes north of Atigun Gorge, but farther north it forms recognizable lateral-moraine segments that are traceable northward into a freestanding end moraine as high 
as $200-250 \mathrm{~m}$ (unit $\mathbf{i d}_{\mathbf{1 A}}$ ). Dynamic ice retreat is indicated by at least 14 closely nested lateral moraines east and southeast of Toolik Lake. These are separated by slightly arcuate drainage swales that follow former icemarginal meltwater channels.

A topographically distinct inner moraine (unit id ${ }_{1 \mathrm{~B}}$ ) is separated from the outer moraine by well-defined marginal drainage channels. This feature extends southward into the west flank of the Kuparuk-Toolik upland, where a belt of water-washed bouldery lag gravel (unit id $_{1}$ with diagonal overprint) may mark the former ice limit along this steep slope. The inner moraine could represent a significant readvance of the Itkillik I glacier, but evidence for this is inconclusive.
In the eastern part of the map, the west flank of the Sagavanirktok valley glacier overtopped drainage divides to spread westward as several individual lobes into the Kuparuk-Toolik uplands. The largest lobe, which extended at least $5.5 \mathrm{~km}$ into the headwaters of Toolik River, formed an irregular deposit with abundant kettles (unit id d $_{1}$ ) that is flanked to the west by lag deposits of bouldery coarse gravel (id $\mathbf{i d}_{\mathbf{1}}$ and $\mathbf{i o}_{\mathbf{1}}$ with diagonal overprint) and to the northwest by a train of outwash gravel (unit $\mathbf{i o}_{1}$ ). Following its advance, the glacial lobe probably stagnated because its irregular kame-and-kettle topography lacks recognizable recessional moraines. A second ice lobe farther north extended a short distance up the steep southern flank

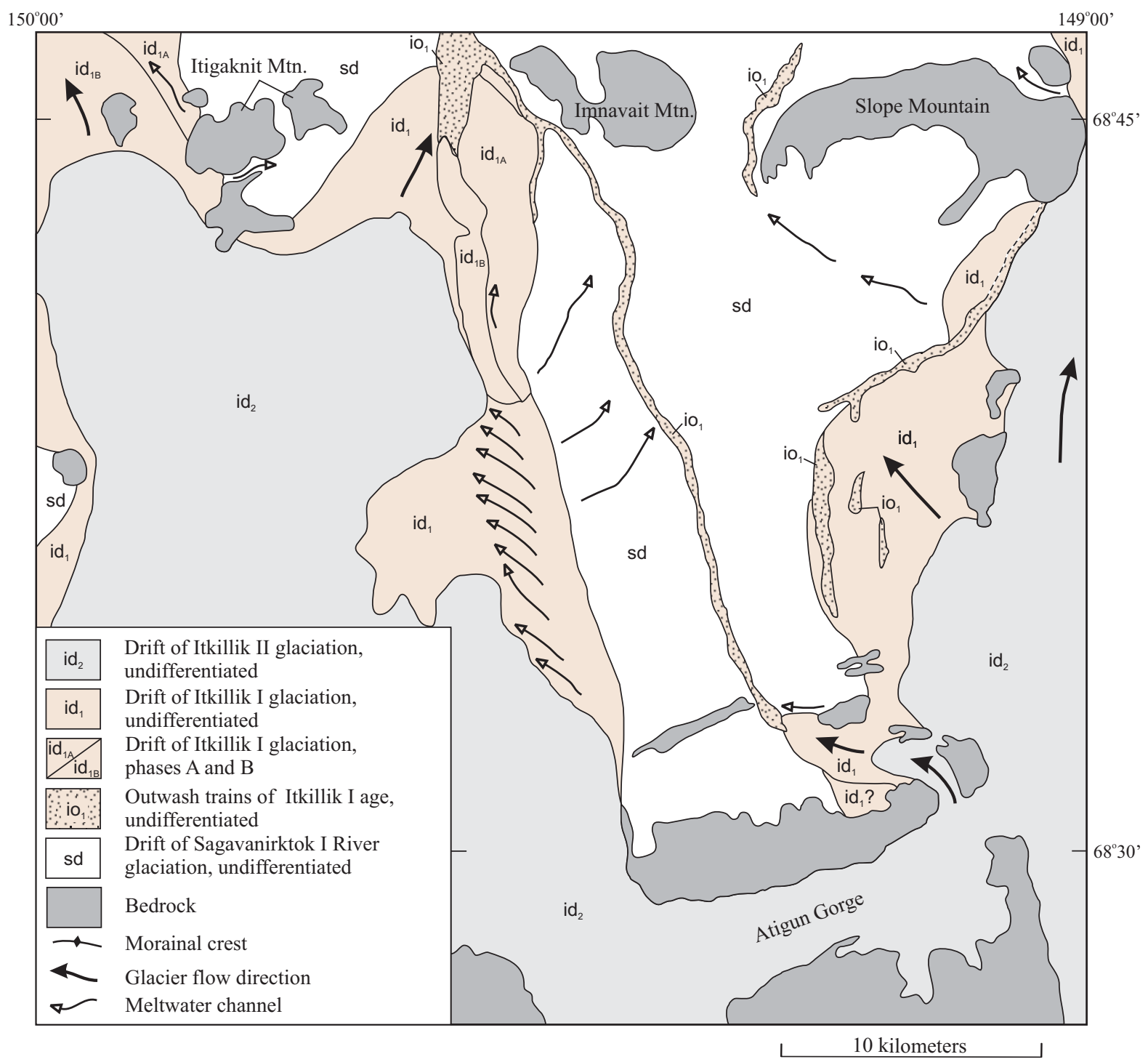

Figure 6. Distribution of drift and outwash of Itkillik I glaciation (colored). Light shading shows extent of subsequent overlap by glaciers during Itkillik II time. 
of Slope Mountain. Much of this drift has been obscured by solifluction and eroded by meltwater that was confined between the glacier and the mountain flank.

The east fork of Toolik River transported meltwater westward from the ice front, but down a gradient too steep to allow significant outwash deposition. Meltwater erosion of drift of Sagavanirktok River age (diagonal overprint areas of unit sd) was more common. The incised channel of the east fork differs from the silt-rich valley fills of Toolik River's main branch and of Kuparuk River, which accumulated undisturbed for a long interval following the Sagavanirktok River glaciation. Solifluction development along the east fork is also much more limited than that along the other drainages. Some outwash of Itkillik I age probably occurs along the east fork, but more extensive outwash-terrace remnants occur along Toolik River near the north margin of the map area. The outwash within higher terraces in this area was probably deposited during the Sagavanirktok River glaciation and then exhumed during Itkillik I time.

Ice of Itkillik I age that probably was derived from the Sagavanirktok valley also spilled over the north rim of Atigun Gorge at its east end and flowed westward for $7 \mathrm{~km}$ into the head of the Kuparuk drainage. Several arcuate, nested end moraines bordered by ice-marginal meltwater channels mark the former terminal zone. An outwash apron originates at the outer moraine and is traceable intermittently down the present course of Kuparuk River.

\section{Itkillik II Phase}

The flow pattern of Itkillik II glaciers was similar to that of Itkillik I ice advances. Glaciers entered the map area from the mountain valleys of the present-day Itkillik, Atigun, and Sagavanirktok rivers (fig. 7). The Itkillik valley and Sagavanirktok valley lobes were of similar size, but the much smaller Atigun lobe extended only $11 \mathrm{~km}$ beyond the range front. Drift limits of Itkillik II age are marked by sharp moraine fronts that rise above the heads of conspicuously channeled outwash aprons. Drift surfaces are more irregular, stonier, less vegetated, and lithologically more varied than those of Itkillik I age (table 2).

Moraines of Itkillik II age have sharp crests and steep flanking slopes. They retain minor surface features such as cross-cutting meltwater channels, multiple crests, and small ridges or benches along their flanks; and they have first-generation ice-wedge polygons with sharp margins. Vegetation is Dryas heath, with dwarf willows and dwarf birches present in the deepest swales (Walker and Walker, 1996). Soils are less well developed than those on deposits of Itkillik I age (Munroe and Bockheim, 2001). Surface boulders commonly pro- trude to half or more of their diameters and to heights of $60-80 \mathrm{~cm}$. Solifluction occurs only locally on lower slopes, and most upper slopes lack colluvial cover. Channeled outwash surfaces generally have only a thin (about $0.3 \mathrm{~m}$ ) cover of frost-mixed gravel and silt. Narrow aprons of solifluction debris are beginning to encroach on their edges, but many drainage swales still retain their original gravel floors. Surface drainage is poorly integrated, and many kettles are isolated from streams. Kettles have flanking slopes close to angles of repose; they have angular to sub-angular outlines, and many retain extreme irregularities such as peninsulas and islands. Their shores are partly vegetated, with bare gravel exposed around much of their perimeters. Some kettles (shown as unit $\mathbf{i k}_{\mathbf{a}}$ ) are still actively forming. These features have bare, unstable flanks, open tension cracks, turbid water, and active flows or slumps along their banks.

Much of the drift of Itkillik II age in the map area forms massive ice-stagnation deposits that lack clear recessional features. However, evidence for two readvances is widely present (fig. 8).

\section{ITKILLIK VALLEY LoBE}

Within the Itkillik valley north of the range front, the glacier of Itkillik II age divided into two lobes that flowed northwest and northeast past the south flank of Itigaknit Mountain (sheet 1). The eastern lobe extended into the area north and west of present-day Toolik Lake, where it formed extensive ice-stagnation deposits with numerous irregular kettles (unit $\mathbf{i d}_{\mathbf{2 A}}$ ). Water-washed deposits of sandy gravel form ridges, flat-topped mounds, and irregular bodies (unit ic) within the drift complex. These features probably were formed by meltwater that flowed beneath the stagnating glacier, and perhaps later occupied ice-walled open channels as the glacier continued to thin. A major meltwater outlet formed extensive gravel deposits along the east shore of Toolik Lake, and extended northeast from the lake into a narrower channel that skirts the east end of the Itkillik II drift complex. Farther north this drainageway feeds into an outwash apron (unit $\mathbf{i}_{2 \mathrm{~A}}$ ) and into a train of water-washed boulder pavement (unit id ${ }_{1}$ with diagonal overprint) that extends past the north margin of the map. Toolik Lake could not have existed when this meltwater system was active; it must have formed later by melt-out of stagnant glacier ice that was buried beneath ice-contact and outwash deposits.

An inner drift complex with a sharply defined outer limit and abundant ice-marginal drainage channels (unit $\mathbf{i d}_{2 \mathrm{~B}}$ ) formed during a probable glacial readvance into the Itkillik II terminal zone. Absence of recessional moraines and abundance of ice-contact meltwater deposits indicates that ice stagnation probably followed 


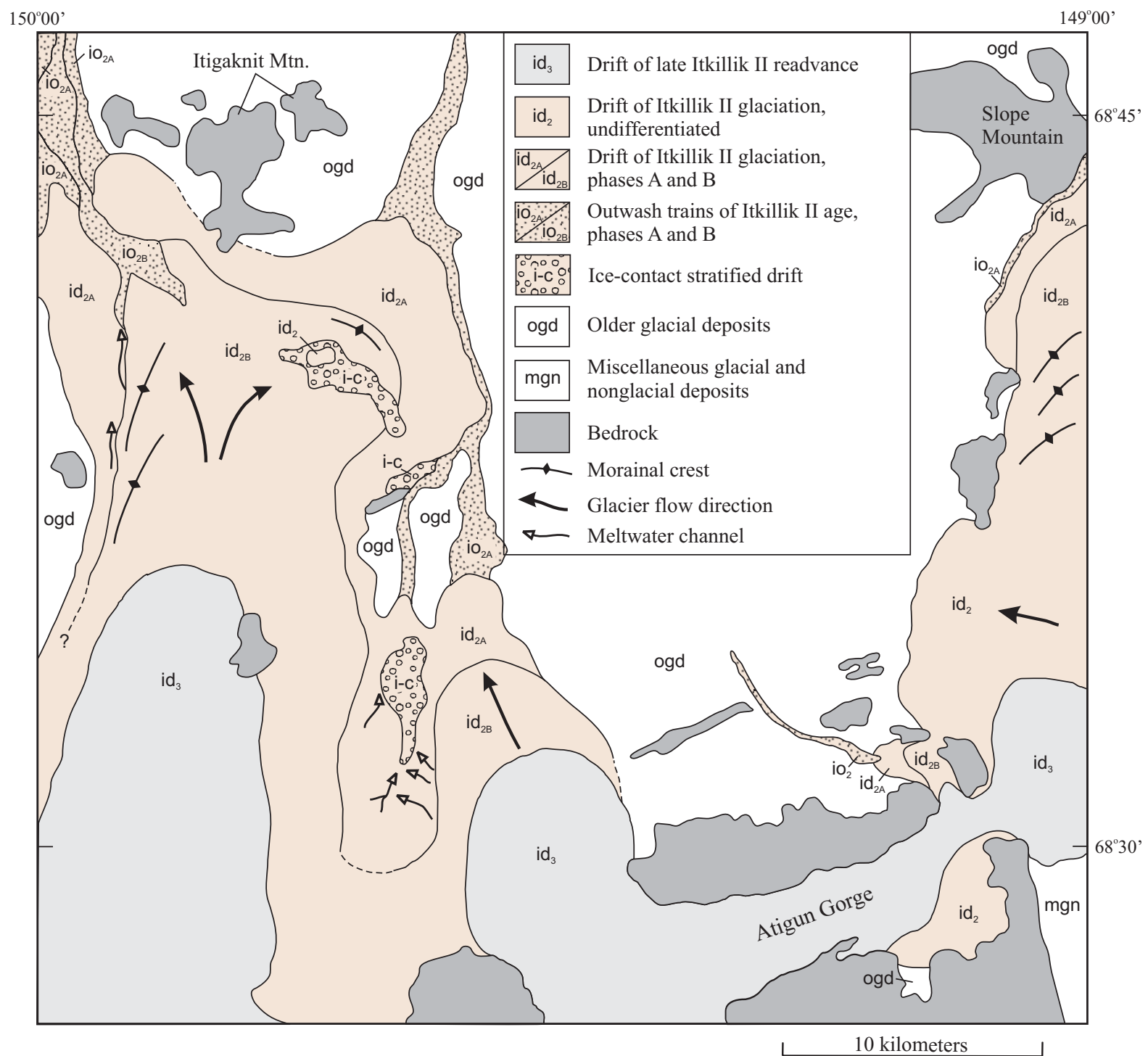

Figure 7. Distribution of drift and outwash of Itkillik II glaciation (colored). Light shading shows extent of subsequent overlap by glaciers during late Itkillik II readvances.

the readvance. A silt-rich blanket of probable glaciolacustrine deposits (unit igl?) may have formed as the glacier downwasted.

\section{Atigun Valley Lobe}

Despite the unusually subdued appearance of its outermost drift, drainage relationships indicate that the glacier of Itkillik II age that originated in Atigun valley must have extended to within $4 \mathrm{~km}$ of present-day Toolik Lake. The drift of the outermost Atigun lobe is more vegetated and less stony than that north and west of Toolik Lake, and its kettles have more smoothly rounded perimeters. However, a broad outwash train that originates at the north limit of this drift complex extends north to Toolik Lake and merges smoothly with the outwash from the larger Itkillik valley lobe. Outwash from the Itkillik valley lobe also skirts the west flank of the Atigun lobe and merges with its outwash apron. These relations show that the Itkillik valley and Atigun valley lobes (designated $\mathbf{i d}_{2 \mathrm{~A}}$ on sheet 1 ) must be of similar age. The more subdued morphology of the Atigun moraine may be due to unusually thick loess cover, which reflects an abundant silt source in the extensive late-glacial and postglacial lakebeds along the floor of Atigun valley south of Galbraith Lake (Hamilton, 1978). In addition, if similar lakebeds formed at the close of Itkillik I glaciation, large amounts of lacustrine silt and fine sand may have been eroded by the advancing glacier of Itkillik II age and incorporated in its drift. Abundant fines within the drift would contribute to its subdued appearance. 


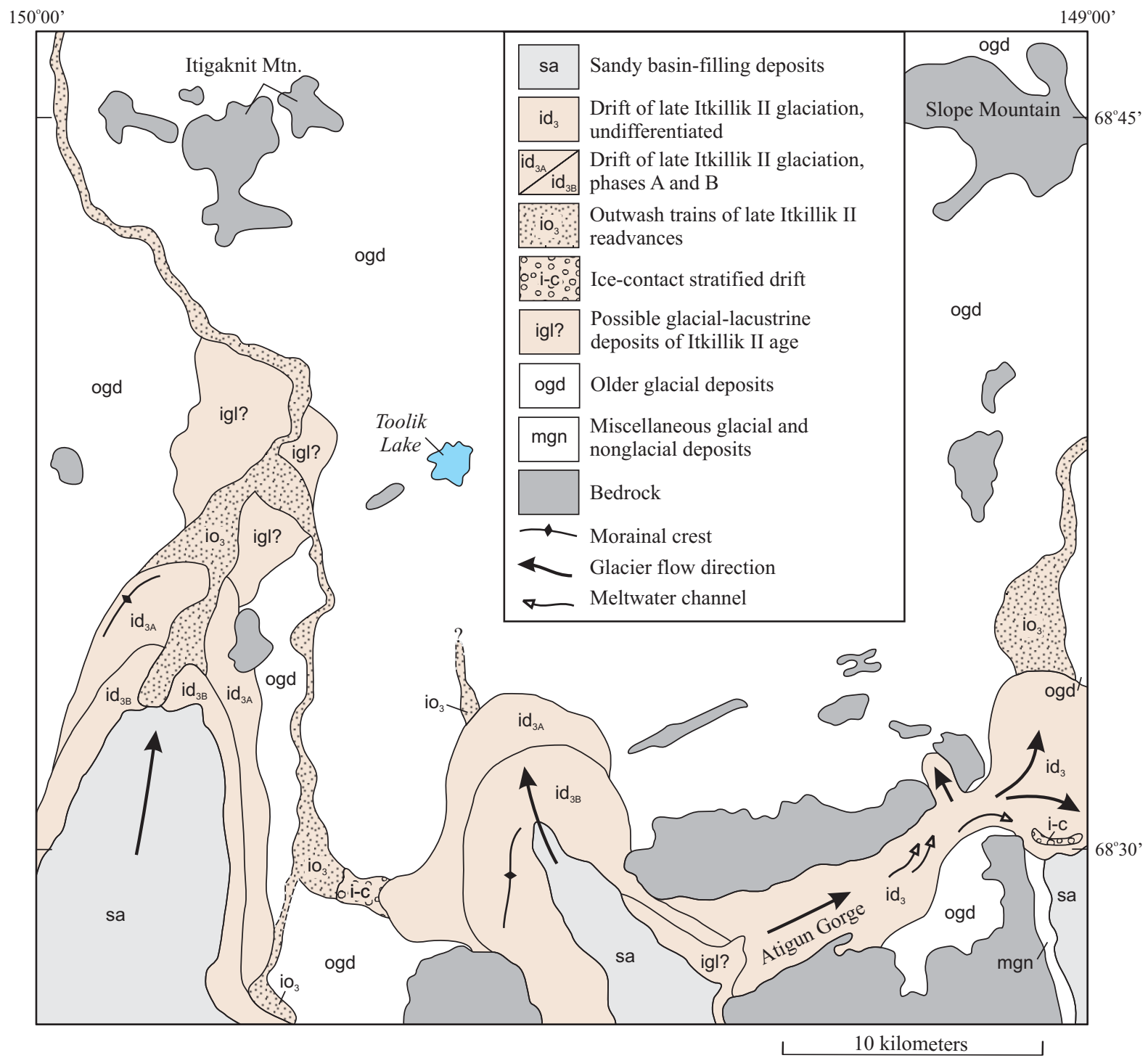

Figure 8. Distribution of drift and outwash of late Itkillik II readvances (colored). Unit igl is probable lake deposits enclosed within outer Itkillik II moraine belt. Light shading shows extent of sandy basin-filling deposits enclosed within double end-moraine belts in Itkillik and Atigun river valleys and dammed by piedmont lobe in upper Sagavanirktok River valley.

A later readvance of the Itkillik II glacier terminated about $3 \mathrm{~km}$ farther south. The Itkillik valley and Atigun valley glaciers did not coalesce at this time, but their meltwater contributed to an extensive body of ice-contact deposits between the two glaciers. Stagnant glacier ice of the initial advance of the Itkillik glaciation must still have been widespread when the readvance took place.

\section{SagavaniRktok Valley Lobe}

At its maximum extent during Itkillik Phase II glaciation, the west flank of the Sagavanirktok valley glacier formed a prominent complex of lateral moraines along the east margin of the Kuparuk-Toolik upland. Near Slope Mountain, the outermost glacial deposits, which formerly were continuous with Itkillik II drift in the Sagavanirktok valley center, have been partly eroded by meltwater. Farther south, the Itkillik II limit is poorly defined for about $6 \mathrm{~km}$ along the steep west wall of Sagavanirktok valley, but beyond this zone the valley wall is lower and a steep-sided, narrow moraine complex forms its crest and upper slopes. The moraine is at the same level as, and nearly continuous with, a narrow drift tongue (unit $\mathbf{i d}_{\mathbf{2 A}}$ ) that extends about $2.5 \mathrm{~km}$ westward from the north rim of Atigun Gorge to the head of Kuparuk River. 
A subsequent readvance of the Itkillik II glacier cannot be distinguished along the steep west wall of Sagavanirktok valley, but closer to Slope Mountain the steep front of a younger moraine complex rises sharply above the water-scoured surface of the outermost Itkillik II drift. The younger drift sheet (shown as unit $\mathbf{i d}_{\mathbf{2 B}}$ ) has the stony, boulder-littered, irregular surface characteristic of Itkillik II deposits, and its kettles have subangular outlines. Meltwater that issued from the readvancing glacier was confined between the ice front and the steep face of Slope Mountain, and it must have eroded most of the outermost Itkillik II deposits.

\section{Late Itkillik II Readvances}

\section{ItKILLIK AND A TIGUN V ALlEy GLACIERS}

During a final readvance at the close of the Itkillik glaciation, glaciers again flowed north from the mouths of Itkillik and Atigun valleys, extending $19 \mathrm{~km}$ and $10 \mathrm{~km}$, respectively, north of the range front (unit id $\mathbf{i d}_{\mathbf{3 A}}$ on fig. 8 and sheet 1). A distributary tongue of the Atigun glacier also flowed east through Atigun Gorge into the Sagavanirktok valley. Inner moraine complexes (unit id $\mathbf{d}_{3 \mathrm{~B}}$ ) are nested within the outer moraines in both Itkillik and Atigun valleys, representing glacier readvances into the terminal zones or possibly major stillstands. Despite its well-documented young age (see Radiocarbon Chronology), the inner moraine of the Atigun glacier has a silty, vegetated surface, with broad crests, gentle slope angles, and sparse erratic boulders. It must contain abundant fine sediments derived by glacial erosion and postglacial wind scour from extensive lakebeds in Atigun valley. A major outwash train that issued from the Atigun glacier (unit $\mathbf{i o}_{3}$ ) extended west and north into the Itkillik valley, where it merged with outwash from the Itkillik valley ice tongue. Outwash from the pair of moraines in the Itkillik valley forms a single unit, indicating that deposition of the two moraines probably took place during a short interval of time.

Extensive sandy deposits (unit sa) fill depositional basins behind the moraine complexes in both Itkillik and Atigun valleys. The smooth flanks of both basins, which lack lateral moraine remnants and ice-marginal channels, indicate that these depressions probably were created by downwastage of stagnating ice rather than dynamic retreat of the glaciers.

\section{Glaciers in the Sagavanirktok Valley}

The eastern distributary of the Atigun glacier flowed east through Atigun Gorge and formed a piedmont lobe that crossed the Sagavanirktok valley floor (unit id $\mathbf{i d}_{\mathbf{3}}$ ). Ice-marginal drainage channels at altitudes up to 900 $\mathrm{m}$ near the mouth of Atigun Gorge decline eastward; they contact the heads of linear gravel deposits that extend down the west wall of Sagavanirktok valley and eastward across the piedmont drift lobe (unit i-c). The piedmont lobe partly blocked the Sagavanirktok River, which alluviated $20 \mathrm{~m}$ or more, depositing sandy basin-filling sediments (unit sa) with in situ peat and woody shrubs. Age determinations on these organic remains, described in the Radiocarbon Chronology section, indicate that the ice dam existed between about 12.8 and 11.4 ka (see also Hamilton, 1996).

Ice from the eastern distributary also crossed the north wall of Atigun Gorge near its east end, reoccupying a U-shaped trough that had been eroded by a succession of glacial advances during Itkillik time. Ice extended northward for about $2 \mathrm{~km}$, depositing an end moraine at about $950 \mathrm{~m}$ altitude that forms the presentday drainage divide at the head of Kuparuk River. The ice lobe evidently carried little debris, because its deposits generally form thin and discontinuous patches over bedrock.

The Sagavanirktok valley glacier was surprisingly small during the time the Atigun Gorge lobe was active. Although it drained numerous cirques at the valley head, it terminated about $22 \mathrm{~km}$ upvalley from the mouth of Atigun Gorge, far beyond the south margin of the map.

\section{POSTGLACIAL DEPOSITS}

Recently deglaciated valley walls and mountain fronts were modified by accumulations of talus rubble (unit tr); lower slopes and drift surfaces were modified by solifluction (s). Undifferentiated colluvial deposits (c), which generally are mixtures of talus and solifluction detritus, occur on many intermediate slopes. Landslide (Is) and flow (fl) deposits formed more locally, as did steep alpine fans (unit af). Through the southern part of the map, these slope deposits are mainly of Holocene age. Farther north, they began forming earlier, commonly during middle Pleistocene deglaciations.

Continued melt-out of buried glacier ice caused kettles to develop within some Holocene river terraces, and some kettles (unit $\mathbf{i k}_{\mathrm{a}}$ ) continued to enlarge up to the present day on glacial deposits north of Toolik Lake and northwest of Galbraith Lake.

The most striking Holocene-age features within the map area occur on the floors of valleys abandoned by glaciers during and after Itkillik II time. The Itkillik and Sagavanirktok rivers downcut through moraine complexes, forming paired and non-paired fluvial terraces. Extensive sandy basin-filling deposits of fluvial and eolian origin accumulated behind moraine dams in Itkillik, Atigun, and Sagavanirktok river valleys. These valley floors later underwent episodes of downcutting and alluviation in response to changes in base levels 
and sediment load generated by climate fluctuations and perhaps landslides and tectonism.

\section{Itkillik Valley Floor}

An extensive body of sand (unit sa) was deposited by the Itkillik River and its tributaries which, partly dammed by the end moraines deposited during late Itkillik II readvances, flowed sluggishly across the resulting depositional basin. The sand deposit stands as high as $18 \mathrm{~m}$ above the modern river, but a set of lower alluvial terraces provides a chronology of downcutting and alluviation during middle and late Holocene time (see Radiocarbon Chronology).

\section{Galbraith Lake Area}

During southward glacier retreat up Atigun valley, an elongate lake formed behind the moraine complex that encloses present-day Galbraith Lake. The lake expanded southward as the glacier retreated, and at its maximum it extended at least $18 \mathrm{~km}$ upvalley from Galbraith Lake's modern south shore (Hamilton, 1978). Drill records within the basin show an irregular bedrock surface overlain by lacustrine silt and clay that locally is more than $15 \mathrm{~m}$ thick (Kreig and Reger, 1982, p. 82-83). The lacustrine deposits generally become increasingly sandy and ice-rich at shallow depths.

Sandy beds dating from a higher lake stage (unit sa) also extend at least $4.2 \mathrm{~km}$ north of Galbraith Lake, and beach ridges (unit b) are present near the margin of these deposits. Higher water-lain gravel benches (unit gr) farther to the north and west may represent an early stage of glacio-lacustrine deposition that began as the Atigun glacier started to retreat from its end-moraine belt.

Two large fan-deltas have built out into the west side of Galbraith Lake. The upper segments of these deposits (facies fd-gr) are dominantly coarse gravel; their sandy distal segments (facies fd-sa) may have formed subaqueously when the lake was at a higher level.

\section{Lower Atigun River and Sagavanirktok Valley Floor}

Beyond the east end of its canyon, the Atigun River flows across a broad alluvial-fan complex. Younger gravel deposits on the fan are graded to the modern floodplain of the Sagavanirktok River; inactive fan deposits (units $\mathbf{f}_{\mathrm{iB}}$ and $\mathbf{f}_{\mathrm{iA}}$ ) appear to be graded to higher Sagavanirktok River floodplain levels.

Channel and floodplain deposits of the Sagavanirktok River are flanked by alluvial terraces, the oldest of which may in part be of glacial origin. Discontinuous remnants of the highest terraces (units ic and $\mathbf{t g}$ ), which stand as much as $50 \mathrm{~m}$ above the river, occur along both sides of the Sagavanirktok River north of the Atigun River fan. Their surfaces locally are flat, but elsewhere are irregular and deeply kettled; ice-contact sand and gravel are exposed along their flanks where the deposits are highest. These terraces must have formed by the Sagavanirktok River flowing across stagnant glacier ice during its retreat from the Itkillik II moraine belt.

A younger set of terraces (units $\mathbf{i o}_{\mathbf{3}}$ and $\mathbf{i o}_{\mathbf{3}}$ ?) that stands 6-15 $\mathrm{m}$ high has smooth, well-drained surfaces that retain faint channel scars. Sparse kettles with subangular outlines indicate that some glacier ice was still present on the valley floor during their formation. These deposits appear to originate from the Atigun piedmont lobe, and probably formed as outwash.

\section{DISCUSSION AND CONCLUSIONS}

The complex glacial pattern of the map area was controlled by repeated advances of middle and late Pleistocene glaciers that flowed north through valley systems now occupied by the Itkillik, Atigun, and Sagavanirktok rivers. Tectonism also impacted the glacial record, probably elevating the Kuparuk plateau and causing its virtual abandonment by glaciers of late Sagavanirktok and younger age. Tectonic activity probably also contributed to piracy via Atigun Gorge of the Atigun drainage by the expanding Sagavanirktok drainage system.

Glacial deposits are assigned to two principal advances of the Sagavanirktok River (middle Pleistocene) glaciation and to three double advances of Itkillik (late Pleistocene) age. During one or more older advances of Sagavanirktok River age, large valley glaciers flowed north along the Itkillik, Kuparuk, and Sagavanirktok drainages. At that time, the Itkillik and Kuparuk drift sheets were nearly equivalent in size (see fig. 2), but the much larger Sagavanirktok valley drift sheet indicates that this valley system had already become a master drainage network. Moraines of older Sagavanirktok River age are massive but subdued, with heavy loess cover, broad flanks smoothed by solifluction, and thick accumulations of ice-rich silt between morainal ridges. The subsequent less extensive advances of late Sagavanirktok River age overflowed into the upper Kuparuk drainage from the west, south, and east. The former Kuparuk valley floor must have been elevated into a plateau by this time, presumably by tectonism, and no longer was connected to the bedrock valley now occupied by Atigun River. Moraines and outwash remnants of late Sagavanirktok River age are closer in appearance to those of the Itkillik I advance than they are to those of the preceding advances. One or more major interglacial intervals must have separated the youngest and oldest advances of Sagavanirktok-age glaciers. 
Itkillik I glaciers flowed strongly northward along the Itkillik and Sagavanirktok drainage systems, but extended a much shorter distance beyond the mouth of Atigun valley (see fig. 2). Upper parts of Atigun drainage may have been pirated prior to this time by westward extension of a prominent western fork at the head of the Sagavanirktok River valley (see fig. 1). At their maximum extent, glaciers of Itkillik I age abutted divides to the west, east, and south of the Kuparuk plateau, but overflowed those divides only locally. Evidence for a younger advance of Itkillik I age is exposed only locally in the map area, but is more widely present farther north in the Itkillik and Sagavanirktok River valleys (see fig. 2).

The subsequent Itkillik II advance, which dates between about 25 and $11.5 \mathrm{ka}$ (Hamilton, 1982b), was in phase with late Wisconsin glaciation elsewhere in Alaska. It is represented by little-modified moraines with stony crests and steep flanks, outwash trains with channeled surfaces, and irregular kettles with gravelly rims. Glacial flow patterns were generally similar to those of present-day river drainage. Two major advances of Itkillik II age took place between about 25 and $17 \mathrm{ka}$, forming extensive ice-stagnation features in the Itkillik and Sagavanirktok River valleys, around Toolik Lake, and north of Galbraith Lake. A subsequent readvance, also with double moraines, is dated between about 12.8 and $11.4 \mathrm{ka}$ at its type locality near the east end of Atigun Gorge (see Radiocarbon Chronology).

Because of continuous permafrost, buried glacier ice may persist for long periods after each advance, and unstable, actively enlarging kettles within the map area indicate that subsurface ice must be melting out today within drift sheets of Itkillik II age. Other active kettles have been mapped on drift sheets of Itkillik I as well as Itkillik II age beyond the north flank of the Brooks Range farther to the west (Hamilton, 1979a, 1980, 1982a). Relict glacier ice may be widely present throughout the zone of continuous permafrost, having been reported from the Canadian Arctic (Fujino and others, 1988; St. Onge and McMartin, 1989), northern Greenland (Houmark-Nielsen and others, 1994), and northern Siberia (Astakhov, 1992; Astakhov and others, 1996; Vaikmae and others, 1993). This complicates relative-age assignments for glacial deposits based on extent of postglacial weathering, soil formation, and modification of relief features; it also constitutes a serious hazard for engineering structures.

Surficial deposits of Holocene age, although less extensive than those of the Pleistocene glaciations, are locally significant along valley floors and on lower parts of ridge flanks and mountain slopes within the map area. Where radiocarbon-dated, these deposits are discussed in the following section.

\section{RADIOCARBON CHRONOLOGY INTRODUCTION}

In this section I discuss 33 radiocarbon ages obtained from 19 localities within or bordering the map area (table 3 ). Eleven radiocarbon determinations were acquired during the present project, and are reported here for the first time. The others were obtained by myself and others on earlier projects, and were reported initially in Hamilton (1978). All ages are presented in radiocarbon years B.P. (Before Present), with no attempt made to convert to calendar years. In subsequent discussion of the ages, I generally shorten them to ka (thousand radiocarbon years B.P.).

The radiocarbon localities are discussed by drainage system from west (Itkillik River valley) to east (Sagavanirktok River valley). Within each drainage, I generally begin with the oldest dated locality and proceed to the youngest. All localities present within the map area are plotted on sheet 1 . Some other localities (designated by italics) lie short distances beyond the south margin of the map, but are included here because their radiocarbon ages help to date or clarify events that took place within the map area.

\section{ITKILLIK RIVER VALLEY}

Nine radiocarbon determinations are available from seven localities along the floor of Itkillik River valley. Most are from riverbanks and bluffs.

\section{Sample 016}

A vegetated bluff face $13.3 \mathrm{~m}$ high occurs along the west side of Itkillik River $4 \mathrm{~km}$ north-northeast of the main mouth of Itikmalak Creek. Inland from the bluff crest, the ground slopes upward to a planar, near-horizontal, sandy surface $18 \mathrm{~m}$ above present river level. A shallow exposure at the crest of the bluff contains dark gray, organic, silty fine sand in beds 0.5 to $1.5 \mathrm{~cm}$ thick (fig. 9A). A trench dug into the bluff face from $12 \mathrm{~m}$ height down to $10 \mathrm{~m}$ above the river exposes subhorizontal beds of medium to coarse sand about 2$4 \mathrm{~cm}$ thick. A piece of detrital wood $1.5 \mathrm{~cm}$ in diameter taken from the base of the trench at $10 \mathrm{~m}$ above river level was dated as $\mathbf{1 1 , 2 6 0} \pm \mathbf{7 0}$ yr B.P.

The 18-m surface probably represents the level to which basin-filling took place shortly after deglaciation. The organic silty sand at the bluff crest may represent overbank deposits formed during subsequent downcutting from the $18-\mathrm{m}$ level. The radiocarbon age of about $11.3 \mathrm{ka}$ on detrital wood within the bluff sediments may date the time of initial basin filling, but its detrital origin indicates that it could also have been eroded from an older deposit and later incorporated in the alluvium that now is exposed in the bluff face. 
Table 3. Selected radiocarbon data, Itkillik River-Sagavanirktok River area

RADIOCARBON DETERMINATIONS RESULTING FROM THIS STUDY

\begin{tabular}{|c|c|c|c|c|}
\hline $\begin{array}{l}\text { Sample } \\
\text { number }^{\mathrm{a}}\end{array}$ & $\begin{array}{c}\text { Latitude/Longitude } \\
\text { and Drainage }\end{array}$ & $\begin{array}{l}\text { Radiocarbon Age } \\
\text { and Lab Numberb }\end{array}$ & $\begin{array}{c}\text { Material } \\
\text { dated }\end{array}$ & Comments \\
\hline 01AHa001 & $\begin{array}{l}68^{\circ} 42.7^{\prime} \mathrm{N} / 149^{\circ} 54.1^{\prime} \mathrm{W} \\
\text { Itkillik Valley }\end{array}$ & $\begin{array}{l}10,120 \pm 50 \\
(\text { Beta-160799) }\end{array}$ & Peaty humic silt & $\begin{array}{l}\text { River bluff } \\
\text { Exhumed tundra soil, A horizon }\end{array}$ \\
\hline 01АНа004 & $\begin{array}{l}68^{\circ} 27.3^{\prime} \mathrm{N} / 149^{\circ} 22.6^{\prime} \mathrm{W} \\
\text { Atigun Valley }\end{array}$ & $\begin{array}{l}1,660 \pm 70 \\
(\text { Beta- } 160800\end{array}$ & Bryophytic peat & $\begin{array}{l}\text { Stream bluff } \\
\text { Strongly oxidized; with eolian } \\
\text { sand interbeds }\end{array}$ \\
\hline 01АНа008 & $\begin{array}{l}68^{\circ} 26.4^{\prime} \mathrm{N} / 149^{\circ} 58.8^{\prime} \mathrm{W} \\
\text { Itkillik Valley }\end{array}$ & $\begin{array}{l}2,870 \pm 70 \\
(\text { Beta-160801) }\end{array}$ & $\begin{array}{l}\text { Bryophytic peat } \\
\text { with sparse twigs }\end{array}$ & $\begin{array}{l}\text { River bank } \\
\text { Base of } 3.1-\mathrm{m} \text {-thick peat bed }\end{array}$ \\
\hline $01 \mathrm{AHa} 010^{\mathrm{c}}$ & & $\begin{array}{l}5,030 \pm 100 \\
(\text { Beta-160802) }\end{array}$ & Peat & $\begin{array}{l}\text { Thin laminae along } \\
\text { bedding planes }\end{array}$ \\
\hline $01 \mathrm{AHa} 011^{\mathrm{c}}$ & $\begin{array}{l}68^{\circ} 23.4^{\prime} \mathrm{N} / 149^{\circ} 20.7^{\prime} \mathrm{W} \\
\text { Atigun Valley. Same }\end{array}$ & $\begin{array}{l}4,760 \pm 80 \\
(\text { Beta-160803) }\end{array}$ & Wood & $\begin{array}{l}\text { Twig } 2 \mathrm{~cm} \text { diameter } \\
\text { (willow?) }\end{array}$ \\
\hline $01 \mathrm{AHa} 012^{\mathrm{c}}$ & locality as sample A-1 & $\begin{array}{l}4,840 \pm 90 \\
(\text { Beta-160804) }\end{array}$ & Wood & $\begin{array}{l}\text { Detrital; along } \\
\text { bedding planes }\end{array}$ \\
\hline $01 \mathrm{AHa} 013^{\mathrm{c}}$ & 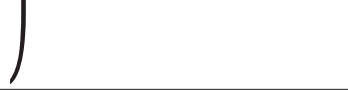 & $\begin{array}{l}4,750 \pm 70 \\
(\text { Beta } 160805)\end{array}$ & Peat and wood & $\begin{array}{l}\text { Detritus near base } \\
\text { of collapse structure }\end{array}$ \\
\hline 01АНа016 & $\begin{array}{l}68^{\circ} 30.2^{\prime} \mathrm{N} / 149^{\circ} 56.3^{\prime} \mathrm{W} \\
\text { Itkillik Valley }\end{array}$ & $\begin{array}{l}11,260 \pm 70 \\
(\text { Beta-160806) }\end{array}$ & Wood & $\begin{array}{l}\text { River bluff } \\
\text { Detrital; } 1.5 \mathrm{~cm} \text { diameter }\end{array}$ \\
\hline 01АНа018A & $\begin{array}{l}68^{\circ} 37.6^{\prime} \mathrm{N} / 149^{\circ} 47.7^{\prime} \mathrm{W} \\
\text { Itkillik Valley }\end{array}$ & $\begin{array}{l}5,660 \pm 40 \\
(\text { Beta-160807) }\end{array}$ & Humic silt & $\begin{array}{l}\text { River bank } \\
\text { Buried tundra soil, A horizon }\end{array}$ \\
\hline 01AHa018B & $\begin{array}{l}68^{\circ} 45.8^{\prime} \mathrm{N} / 149^{\circ} 28.6^{\prime} \mathrm{W} \\
\text { Imnavait Mountain Pass }\end{array}$ & $\begin{array}{l}2,400 \pm 70 \\
(\text { Beta-160808) }\end{array}$ & Bryophytic peat & $\begin{array}{l}\text { Lake shore } \\
\text { Within solifluction deposit }\end{array}$ \\
\hline 01АНа019 & $\begin{array}{l}68^{\circ} 35.8^{\prime} \mathrm{N} / 149^{\circ} 04.3^{\prime} \mathrm{W} \\
\text { Sagavanirktok Valley }\end{array}$ & $\begin{array}{l}7,030 \pm 100 \\
(\text { Beta-160809) }\end{array}$ & $\begin{array}{l}\text { Humic silt with } \\
\text { rootlets }\end{array}$ & $\begin{array}{l}\text { River bluff } \\
\text { Tundra soil buried by basin-fill } \\
\text { deposit }\end{array}$ \\
\hline
\end{tabular}

\section{RADIOCARBON LOCALITIES FROM PREVIOUS STUDIES}

(Hamilton, 1979b unless otherwise noted)

\begin{tabular}{|c|c|c|c|c|c|}
\hline $\begin{array}{l}\text { Locality } \\
\text { number }\end{array}$ & $\begin{array}{c}\text { Latitude/Longitude } \\
\text { and Drainage }\end{array}$ & $\begin{array}{l}\text { Radiocarbon Age } \\
\text { and Lab Numberb }\end{array}$ & $\begin{array}{c}\text { Material } \\
\text { dated }\end{array}$ & \multicolumn{2}{|c|}{ Comments } \\
\hline I-1 & $\begin{array}{l}68^{\circ} 26.3^{\prime} \mathrm{N} / 149^{\circ} 58.6^{\prime} \mathrm{W} \\
\text { Itkillik Valley }\end{array}$ & $\begin{array}{l}4,220 \pm 95 \\
(\mathrm{I}-10,510)\end{array}$ & Wood & \multicolumn{2}{|l|}{ Lake shore } \\
\hline$I-2^{c}$ & $\begin{array}{l}68^{\circ} 25.8^{\prime} \mathrm{N} / 149^{\circ} 59.6^{\prime} \mathrm{W} \\
\text { Itkillik Valley }\end{array}$ & $\begin{array}{l}2,505 \pm 190 \\
(\mathrm{I}-10,520)\end{array}$ & Bryophytic peat & \multicolumn{2}{|l|}{ River bluff } \\
\hline \multirow[t]{3}{*}{ I-3 } & $\begin{array}{l}68^{\circ} 27.2^{\prime} \mathrm{N} / 149^{\circ} 59.7^{\prime} \mathrm{W} \\
\text { Itkillik Valley }\end{array}$ & $\begin{array}{l}430 \pm 50 \\
(\text { USGS-165) }\end{array}$ & Wood & $\begin{array}{l}\text { Roots in growth } \\
\text { position }\end{array}$ & \multirow{3}{*}{$\begin{array}{l}\text { River } \\
\text { bank }\end{array}$} \\
\hline & & $\begin{array}{l}770 \pm 130 \\
(\text { USGS-166) }\end{array}$ & Wood & \multirow[t]{2}{*}{$\begin{array}{l}\text { Roots in growth } \\
\text { position }\end{array}$} & \\
\hline & & $\begin{array}{l}1,275 \pm 80 \\
(\mathrm{I}-10,519)\end{array}$ & Bryophytic peat & & \\
\hline \multirow[t]{2}{*}{$A-1^{c}$} & \multirow[t]{2}{*}{$\begin{array}{l}68^{\circ} 23.4^{\prime} \mathrm{N} / 149^{\circ} 20.7^{\prime} \mathrm{W} \\
\text { Atigun Valley }\end{array}$} & $\begin{array}{l}4,630 \pm 100 \\
(I-10,505)\end{array}$ & Peat and twigs & & \\
\hline & & $\begin{array}{l}4,800 \pm 100 \\
(\text { USGS-42) }\end{array}$ & Peat & & \\
\hline
\end{tabular}


Table 3. Selected radiocarbon data, Itkillik River-Sagavanirktok River area (cont'd)

\begin{tabular}{|c|c|c|c|c|}
\hline $\begin{array}{l}\text { Locality } \\
\text { number }^{\mathrm{a}}\end{array}$ & $\begin{array}{l}\text { Latitude/Longitude } \\
\text { and Drainage }\end{array}$ & $\begin{array}{l}\text { Radiocarbon Age } \\
\text { and Lab Number }\end{array}$ & $\begin{array}{c}\text { Material } \\
\text { dated }\end{array}$ & Comments \\
\hline $\mathrm{A}-2^{\mathrm{c}}$ & $\begin{array}{l}68^{\circ} 25.3^{\prime} \mathrm{N} / 149^{\circ} 22.9^{\prime} \mathrm{W} \\
\text { Atigun Valley }\end{array}$ & $\begin{array}{l}2,000 \pm 80 \\
(\mathrm{USGS}-43)\end{array}$ & Peat & River bluff \\
\hline \multirow[t]{3}{*}{ A-3 } & $\begin{array}{l}68^{\circ} 27.2^{\prime} \mathrm{N} / 149^{\circ} 21.8^{\prime} \mathrm{W} \\
\text { Atigun Valley }\end{array}$ & $\begin{array}{l}740 \pm 100 \\
(B G S-513)\end{array}$ & Wood & $\begin{array}{l}\text { Collected by P.E. Calkin } \\
\text { and J.M. Ellis, } \\
\text { SUNY, Buffalo, NY }\end{array}$ \\
\hline & & $\begin{array}{l}2,245 \pm 120 \\
(\mathrm{I}-10,506)\end{array}$ & Peat & $\begin{array}{l}\text { River } \\
\text { bluff }\end{array}$ \\
\hline & & $\begin{array}{l}2,510 \pm 110 \\
(\mathrm{BGS}-512)\end{array}$ & Peat & $\begin{array}{l}\text { Collected by P.E. Calkin } \\
\text { and J.M. Ellis, } \\
\text { SUNY, Buffalo, NY }\end{array}$ \\
\hline Near A-3 & & $\begin{array}{l}3,080 \pm 65 \\
(\mathrm{DIC}-442)\end{array}$ & In situ twigs & $\begin{array}{l}\text { Collected by D.A. Walker } \\
\text { (Walker et al., 1981) }\end{array}$ \\
\hline A-4 & $68^{\circ} 29.5^{\prime} \mathrm{N} / 149^{\circ} 35^{\prime} \mathrm{W}$ & $\begin{array}{l}1,850 \pm 85 \\
(\mathrm{USGS}-44)\end{array}$ & Peat & \\
\hline \multirow[t]{5}{*}{ S-1 } & $\begin{array}{l}68^{\circ} 29.7^{\prime} \mathrm{N} / 149^{\circ} 01.3^{\prime} \mathrm{W} \\
\text { Sagavanirktok Valley }\end{array}$ & $\begin{array}{l}5,455 \pm 105 \\
(\mathrm{I}-10,817)\end{array}$ & Peat & \multirow{5}{*}{$\begin{array}{l}\text { River bluff. Discussed also } \\
\text { in Hamilton, } 1996\end{array}$} \\
\hline & & $\begin{array}{l}8,930 \pm 140 \\
(\mathrm{I}-10,469)\end{array}$ & Peat & \\
\hline & & $\begin{array}{l}11,360 \pm 170 \\
(\mathrm{I}-11,596)\end{array}$ & $\begin{array}{l}\text { Plant roots } \\
\text { with twigs }\end{array}$ & \\
\hline & & $\begin{array}{l}12,700 \pm 180 \\
(\mathrm{I}-10,468)\end{array}$ & Willow roots & \\
\hline & & $\begin{array}{l}12,840 \pm 160 \\
(\mathrm{USGS}-47)\end{array}$ & $\begin{array}{l}\text { Roots and wood } \\
\text { fragments }\end{array}$ & \\
\hline $\mathrm{S}-2^{\mathrm{c}}$ & $\begin{array}{l}68^{\circ} 24.5^{\prime} \mathrm{N} / 148^{\circ} 58^{\prime} \mathrm{W} \\
\text { Sagavanirktok Valley }\end{array}$ & $\begin{array}{l}11,760 \pm 200 \\
(A U-69)\end{array}$ & Wood fragments & Discussed also in Hamilton, 1996 \\
\hline \multirow[t]{2}{*}{ S-3 } & $\begin{array}{l}68^{\circ} 28.2^{\prime} \mathrm{N} / 149^{\circ} 01.4^{\prime} \mathrm{W} \\
\text { Sagavanirktok Valley }\end{array}$ & $\begin{array}{l}5,310 \pm 100 \\
(\mathrm{I}-10,504)\end{array}$ & Wood fragments & \\
\hline & & $\begin{array}{l}5,270 \pm 105 \\
(\mathrm{I}-10,470)\end{array}$ & Wood fragments & \\
\hline ML & $\begin{array}{l}68^{\circ} 27.0^{\prime} \mathrm{N} / 149^{\circ} 22.0^{\prime} \mathrm{W} \\
\text { Atigun Valley }\end{array}$ & $\begin{array}{l}4,830 \pm 155 \\
(\mathrm{GX}-4078)\end{array}$ & "Organic material" & $\begin{array}{l}\text { Test pit, Mosquito Lake site } \\
\text { (buried paleosol?). From } \\
\text { Kunz 1979, p. } 751\end{array}$ \\
\hline 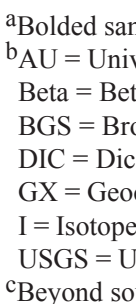 & $\begin{array}{l}\text { e and locality numbers are sh } \\
\text { ity of Alaska } \\
\text { nalytic } \\
\text { University } \\
\text { Corp. } \\
\text { on, Inc. } \\
\text { nc. } \\
\text { Geological Survey (Menlo P } \\
\text { ern margin of map. }\end{array}$ & k Lab.) & & \\
\hline
\end{tabular}




\section{$\underline{\text { A. } 016}$}

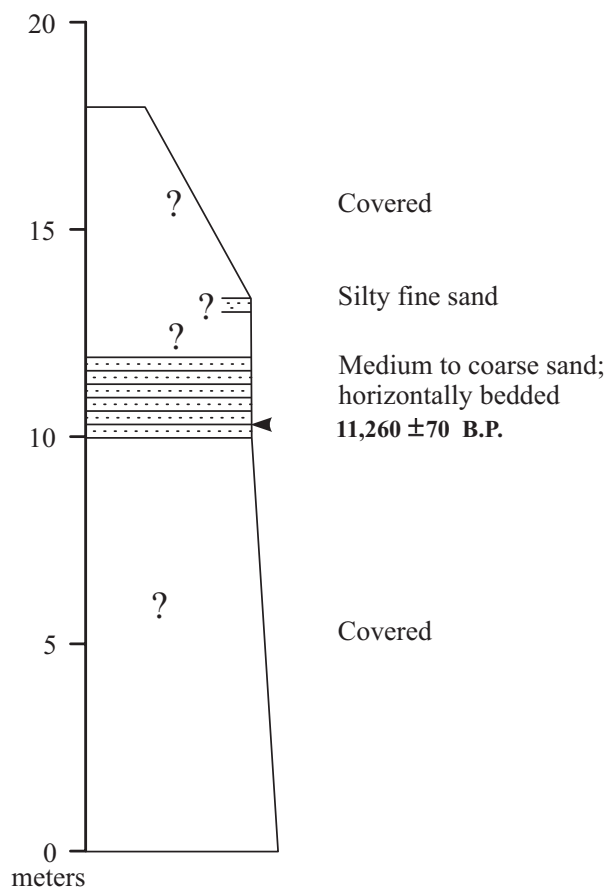

\section{018A}

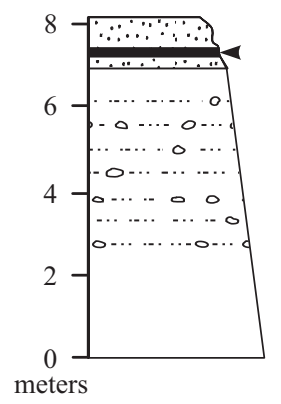

\section{E. I-2}

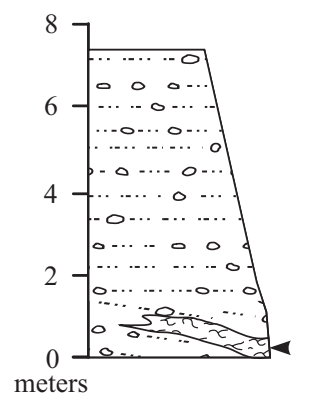

Bedded fluvial sand with intermixed pebbles and cobbles. Bryophytic peat forms local swale-filling deposit at base.
2,505 \pm 190 B.P.
Eolian sand with paleosol $5,660 \pm 40$ B.P.

Alluvium
(mostly covered)

\section{B. 001}

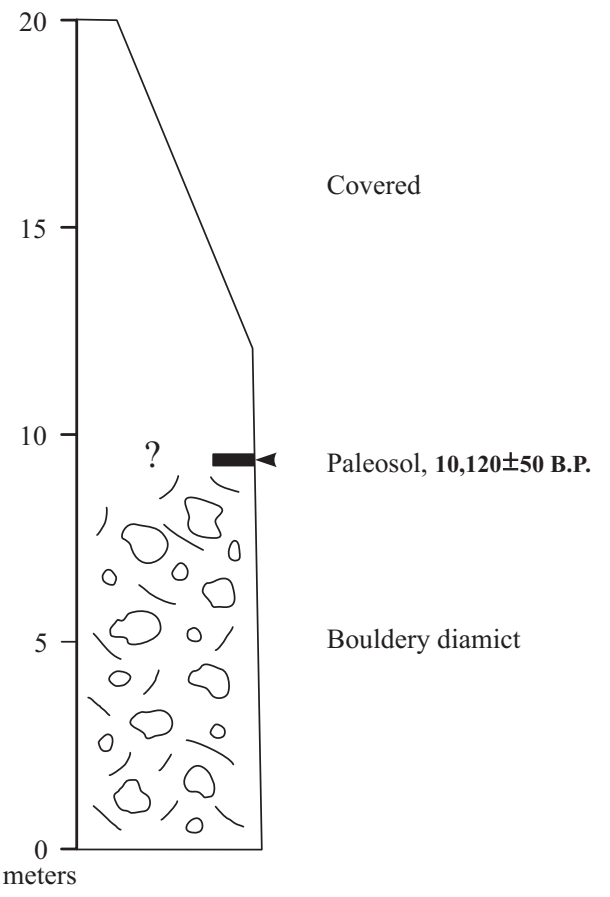

D. 008

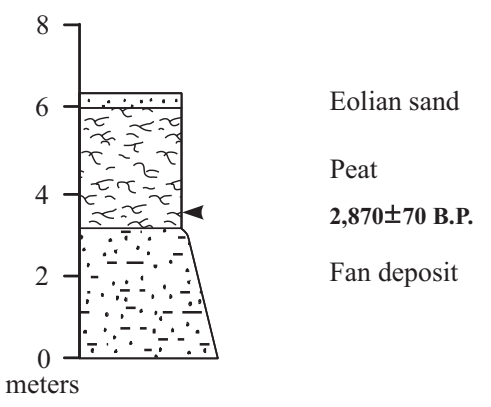

Figure 9. Itkillik valley bluff and bank deposits sampled for radiocarbon analysis during 2001.

A. West side Itkillik River $4 \mathrm{~km}$ north-northwest of Itikmalak Creek (sample 016).

B. Northeast side Itkillik River within Itkillik II moraine complex (sample 001).

C. East side Itkillik River $6.2 \mathrm{~km}$ west of Toolik Lake (sample 018A).

D. West bank Itkillik River opposite main mouth of Itikmalak River (sample 008).

E. Exposure I-2, east side Itkillik River $1.0 \mathrm{~km}$ beyond south margin of map sheet. 


\section{Sample 001}

A 12-m bluff exposure along the northeast side of Itkillik River occurs within the moraine complex of Itkillik II age. The bluff exposes probable glacial till consisting of striated and faceted clasts up to $1.5 \mathrm{~m}$ diameter in an unsorted muddy matrix (fig. 9B). A buried paleosol $10 \mathrm{~cm}$ thick dips upvalley from about 9.8 to $9.4 \mathrm{~m}$ above river level. The paleosol consists of 4 $\mathrm{cm}$ of black humus, which is dated at $\mathbf{1 0 , 1 2 0} \pm \mathbf{5 0} \mathbf{~ y r}$ B.P., above $6 \mathrm{~cm}$ of silt that is mottled with oxides and organic matter. From the bluff crest, the ground surface rises inland at a gentle angle to a terracelike surface $20 \mathrm{~m}$ above the river.

The paleosol is considered to be the A and B horizons of a buried tundra soil. Because the inner moraine (unit id $\mathbf{d}_{2 \mathrm{~B}}$ ) of the Itkillik II complex occurs just upvalley from this site and because of the terracelike 20 -m surface just inland from it, I had expected that a radiocarbon age on the paleosol would date the interstade between the $\mathbf{i d}_{2 \mathrm{~A}}$ advance (the underlying till) and the $\mathbf{i d}_{\mathbf{2 B}}$ readvance (which created the probable 20-m outwash terrace). However, the age of about $10.1 \mathrm{ka}$ on this sample is unexpectedly young. Paleosol A horizons are difficult to date accurately owing to penetration by younger roots and rootlets and to influx of younger humic substances and solutions. The sample's age could be too young for these reasons, or it could be valid and represent a pause in river downcutting from the $20-\mathrm{m}$ terrace level.

\section{Sample 018A}

A bank exposure $8.3 \mathrm{~m}$ high occurs along east side of Itkillik River $1 \mathrm{~km}$ south of the mouth of an unnamed eastern tributary that enters the river $6.2 \mathrm{~km}$ west of Toolik Lake. Limited exposures show the bank to consist dominantly of alluvium that contains subrounded pebbles and small cobbles in an abundant matrix of coarse sand with shale chips (fig. 9C). The alluvium is capped by $90 \mathrm{~cm}$ or more of eolian fine sand or very coarse silt. An organic-rich paleosol, which extends from 50 to $67 \mathrm{~cm}$ depth within the eolian cap, consists of strongly involuted black humic matter and locally oxidized silt above frost-mixed stony silt or silty very fine sand. Humic-rich silt from the paleosol A horizon is dated as $\mathbf{5 , 6 6 0} \pm \mathbf{4 0} \mathrm{yr}$ B.P.

The paleosol is considered to be a buried tundra soil. It overlies sandy alluvium that formed when the Itkillik River flowed $5 \mathrm{~m}$ or more above its present level. The river probably was eroding laterally into older basin-filling sediments at that time, providing abundant sand that intermixed with the river gravel. The paleosol probably formed during a mid-Holocene episode of relative stability that was preceded and followed by accretion of windblown sand.

\section{Exposure I-1}

A bank exposure at the north side of an unnamed kettle lake is situated at the south margin of the map $3.7 \mathrm{~km}$ south of the mouth of Itikmalak River. The bank is $11 \mathrm{~m}$ high and exhibits an eolian sand-sheet deposit above horizontally bedded basin-filling sand (fig. 10). A peat bed 7.5-8.0 $\mathrm{m}$ above lake level at the interface between the eolian and fluvial deposits is dated at $\mathbf{4 , 2 2 0}$ \pm 95 yr B.P.

The peat is part of a paleosol horizon that varies laterally from humic-stained sand to peaty sand and sandy peat. It formed during a period of stability that followed the basin-filling episode by an unknown interval, and probably was followed closely by accumulation of the eolian deposit that buried it. The peat could place a close maximum age on intensified eolian activity in this part of Itkillik valley, or it could merely reflect enlargement of the kettle lake to an extent that allowed cliff-head sand along its north margin to encroach on this site.

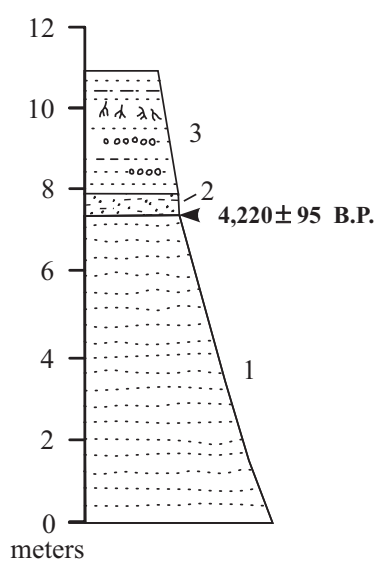

Unit thickness and description

Unit 3 (3 m) - Dark grayish-brown (10YR 4/2) medium sand, containing shale chips of coarse sand to granule size. Weak horizontal bedding, accentuated by roots at distinct growth levels and by thin lenses and beds of shaly granules. Probable cliff-head sand sheet.

Unit $2(0.5 \mathrm{~m})$ - Interbedded dark gray (10YR 4/1) to very dark grayish-brown (10YR 3/2) humicstained to gleyed sand, silty sand, and sandy silt; containing wood fragments. Grades laterally into dark gray to yellowish-brown (10YR 5/6) peaty sand to sandy peat.

Unit $1(7.5 \mathrm{~m})$ - Dark gray (5Y 4/1) medium and coarse sand, interbedded with dark grayish-brown (10YR 4/2) fine sand. Weakly defined near-horizontal bedding.

Figure 10. Exposure I-1. North end of unnamed lake at south margin of map sheet. From Hamilton, $1979 b$. 


\section{Sample 008}

The west bank of Itkillik River opposite the principal mouth of Itikmalak River stands $6.3 \mathrm{~m}$ high. Exposures show thick $(3.1 \mathrm{~m})$ peat above $3 \mathrm{~m}$ of poorly sorted immature sand with abundant shale chips (see fig. 9D). The basal peat, which is dated at $\mathbf{2 , 8 7 0} \pm \mathbf{7 0}$ yr B.P., is bryophytic with sparse twigs; it grades upward into sedge peat with abundant rootlets. A 0.2 -m-thick cap of eolian sand with abundant rootlets overlies the peat.

Immature sand with shale chips is a typical fan sediment. This deposit probably formed part of the large alluvial fan at the mouth of Itikmalak River, which may have been prograding vigorously across the valley center shortly before $2.9 \mathrm{ka}$. The thick peat probably represents a long period of stability that began about $2.9 \mathrm{ka}$, and ended when eolian sand began to accumulate at the site. The sand could represent a general period of intensified eolian activity on the valley floor, but alternatively it could merely reflect renewed progradation of the Itikmalak River fan. Fan extension would cause the opposing bank of Itkillik River to recede, allowing an eolian bluff cap to form at the site.

\section{Exposure I-2}

A 7.8-m-high bluff exposure with a terracelike upper surface occurs along the east side of Itkillik River $1.0 \mathrm{~km}$ beyond the south margin of the map. The exposure consists of bedded fluvial sand with intermixed pebbles and cobbles (see fig. 9E). Bryophytic peat with a radiocarbon age of $\mathbf{2 , 5 0 5} \pm \mathbf{1 9 0} \mathbf{~ y r}$ B.P. forms a local swale-filling deposit near the base of the exposure. It locally dips below present-day river level.

The river must have flowed at a level below present during the episode of peat accumulation about $2.5 \mathrm{ka}$. It subsequently alluviated to a height of nearly $8 \mathrm{~m}$. During alluviation, the river was actively eroding a nearby kamelike complex of gravelly ice-stagnation deposits that protrudes above the valley floor. Gravel derived from the eroded flank of this deposit was mixed with sandy alluvium and deposited at the site.

\section{Exposure I-3}

Two low alluvial terraces of Itkillik River, which stand about 6.5 and $4.0 \mathrm{~m}$ high, extend along its west bank $2.1 \mathrm{~km}$ south of the mouth of Itikmalak River (fig. 11). The higher terrace deposit consists entirely of

\section{SOUTH}

NORTH

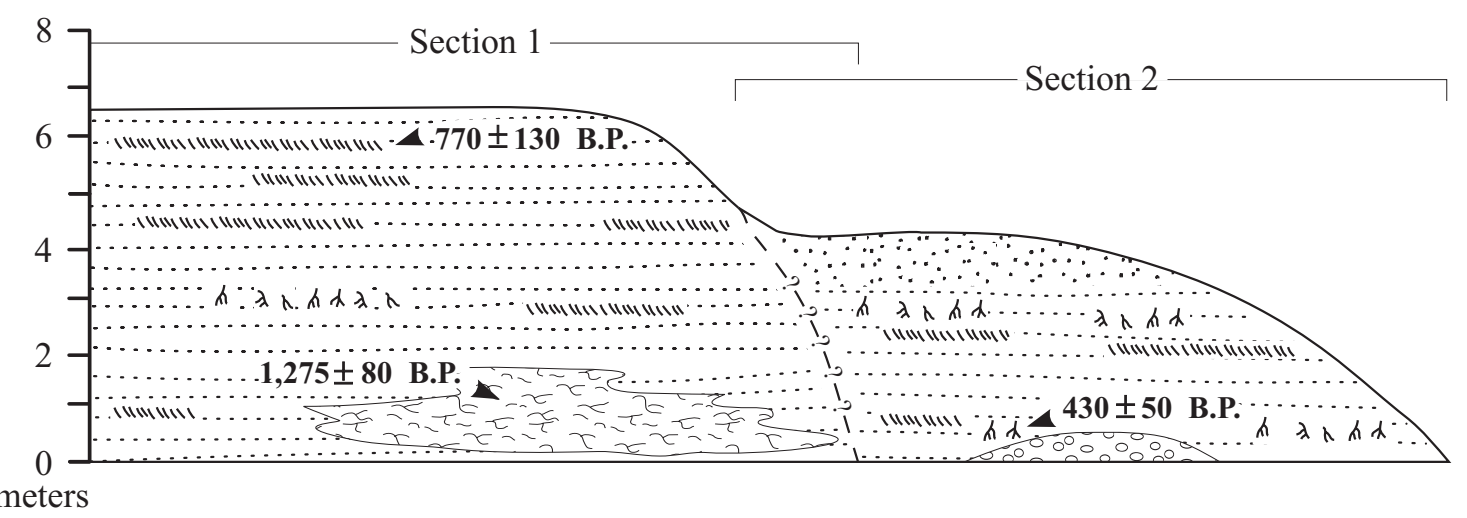

Section thickness and description

Section 2 (4.1 m) - Dark grayish-brown (10YR 4/2) fine sand interbedded with dark gray (5Y 4/1) shaly coarse sand in horizontal beds $1-8 \mathrm{~cm}$ thick. Contains abundant in situ roots and less common peaty sand layers and fragments of detrital wood. Upper $0.5 \mathrm{~m}$ structureless, probably owing to reworking by wind. Lens of fine gravel, locally present at base, consists of subrounded pebbles in a sandy matrix.

Section $1(6.5 \mathrm{~m})$ - Fine sand interbedded with coarse sand containing shale chips, as described above. Upper $3 \mathrm{~m}$ contains abundant mats of grasses and sedges along bedding planes. Basal $2 \mathrm{~m}$ contains lens of byrophotic peat that fills swale in sand.

Figure 11. Exposure I-3, west side Itkillik River $2.1 \mathrm{~km}$ south of mouth of Itikmalak River. From Hamilton, $1979 \mathrm{~b}$. 
fine sand and coarse sand with shale chips, which are interbedded in horizontal strata $1-8 \mathrm{~cm}$ thick. The basal $2 \mathrm{~m}$ of this deposit contains a lens of bryophytic peat, dated at $\mathbf{1 , 2 7 5} \pm \mathbf{8 0} \mathbf{y r}$ B.P., that fills a swale in the sand. The upper $3 \mathrm{~m}$ of the deposit contains abundant mats of grasses and sedges along bedding planes. A root in growth position about $0.5 \mathrm{~m}$ below the terrace surface is dated as $\mathbf{7 7 0} \pm \mathbf{1 3 0} \mathbf{y r}$ B.P.

The face of the lower terrace also dominantly consists of horizontally bedded coarse and fine sand, with abundant in situ roots and less common peaty sand layers and fragments of detrital wood. A lens of fine gravel locally present at its base consists of subrounded pebbles in a sandy matrix. Roots in growth position near the upper surface of the gravel lens are dated as $430 \pm 50$ yr B.P. The upper $0.5 \mathrm{~m}$ of the deposit is structureless sand, which probably has been reworked by the wind.

The three radiocarbon dates from exposure I-3 provide a concordant history of terrace-building at two successive levels during late Holocene time. The higher surface aggraded between about 1.3 and $0.8 \mathrm{ka}$. The Itkillik River subsequently downcut to a position at or below its present level sometime before about 430 years ago, then aggraded again to a level about $3.5 \mathrm{~m}$ above present. It subsequently accumulated an eolian cap about $0.5 \mathrm{~m}$ thick.

\section{ATIGUN RIVER VALLEY}

Twelve radiocarbon determinations were obtained on samples collected from five exposures along Atigun River and the outlet stream from Galbraith Lake near the south-central margin of the map. An additional radiocarbon determination was obtained from an archeological test pit near the mouth of the outlet stream.

\section{Samples 010-013 (Exposure A-1)}

A meander cutbank along the east side of Atigun River $5.5 \mathrm{~km}$ south of the mouth of Galbraith Lake outlet stream (beyond the south margin of the map) has a wellexposed north-facing segment. This bluff stood $15.2 \mathrm{~m}$ above river level when measured in 2001; its measured height was $15.6 \mathrm{~m}$ in 1975, when the river level may have been lower. Near-horizontal beds of silty fine sand to clayey silt near the base of the exposure grade upward into coarser sand and peat and then into coarse sand with shale chips, detrital wood, and sparse pebbles (fig. 12). The bluff is capped by tundra soil that is buried beneath about $0.8 \mathrm{~m}$ of eolian sand. Five radiocarbon ages from the horizontally bedded sediments range from $5,030 \pm 100$ yr B.P. at the base of the section to 4,630 \pm 100 yr B.P. near the top. The part of the bluff face closest to a small kettle on the valley floor exposes a collapse structure that extends $4.4 \mathrm{~m}$ below the surface. Locally derived sandy sediment forms steeply

\section{0-013}

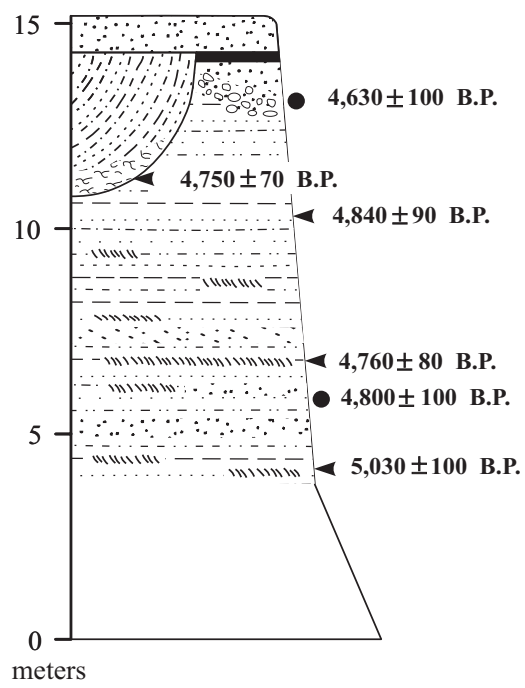

Unit thickness and description

$\underline{\text { Unit } 3}(0.8 \mathrm{~m})$ Bluff cap. Eolian fine sand with abundant rootlets

$\underline{\text { Unit } 2}(0.4 \mathrm{~m})$ Paleosol. Gleyed silty fine sand with frost aggregates and involutions below very dark gray organic horizon (A horizon).

Unit 1 (14.4 m) Sandy to silty basin-filling deposits. Coarsen upward, with gradational contacts.

(4.4 m) Coarse sand with granule-sized shale chips and detrital wood along bedding planes. Faintly bedded. Sparse pebbles in upper $0.5 \mathrm{~m}$.

$(5.0 \mathrm{~m})$ Thin near-horizontal beds of clayey silt, silty very fine sand, and felted peat. Form packages $4-8 \mathrm{~cm}$ thick that alternate with beds of medium sand $8-20$ $\mathrm{cm}$ thick. Prominent peat layer at $6.8 \mathrm{~m}$ height. Medium and coarse sand dominant in upper $2 \mathrm{~m}$.

(1.2 m) Silty fine sand to clayey silt, in near-horizontal beds $0.5-1 \mathrm{~cm}$ thick. Thin beds of felted peat locally present.

(3.8 m) Covered. Presumed continuation of unit 1 (no clasts evident).

Figure 12. East bank Atigun River $4.1 \mathrm{~km}$ beyond south margin of map (samples 010-013). Same as locality A-1 in Hamilton, 1979b. Sample positions marked with dots are from Hamilton, 1979b, and are approximately located on this section. Unit boundaries below paleosol are gradational, and therefore are not shown. 
dipping (about $31^{\circ}$ ) beds above a high-angle unconformity. Detrital peat and wood that are concentrated in a 'trash layer' near the base of this feature are dated at $\mathbf{4 , 7 4 0} \pm \mathbf{7 0}$ yr B.P.

The exposed sediments record rapid deposition within the basin that formed in Atigun valley behind the end moraines of the late Itkillik readvance north of Galbraith Lake. The lower sediments may have formed in standing to very slowly moving water, but the coarser deposits with detrital wood above $10 \mathrm{~m}$ height must be fluvial. The five radiocarbon ages from the horizontally bedded deposits indicate that rapid alluviation took place over an interval of only a few hundred years. The collapse structure, which probably was due to enlargement of the small kettle near the bluff by melt-out of glacier ice, dates from the time that aggradation of the valley floor reached a height of about $14 \mathrm{~m}$. The 4,750year-old peat and wood at the base of the collapse structure may have been derived from the buried tundra soil, in which case it would closely date the time of collapse due to kettle enlargement. Alternatively, the organic detritus could have been redeposited from somewhat older sediments.

\section{Sample 004}

A south-facing exposure $18.8 \mathrm{~m}$ high stands at the apex of a sharp meander bend along the north side of Galbraith Lake's outlet stream about $0.8 \mathrm{~km}$ southeast of the lake. Poorly exposed horizontally bedded sand extends upward to $10.4 \mathrm{~m}$ above river level (fig. 14), but its true thickness is unknown. Oxidized peat with eolian sand interbeds extends from the upper contact of the bedded sand up to $13.8 \mathrm{~m}$ height. A sample taken $0.9 \mathrm{~m}$ below its upper contact is dated as $\mathbf{1 , 6 6 0} \pm \mathbf{7 0} \mathbf{~ y r}$ B.P. The bluff is capped by $5 \mathrm{~m}$ of eolian sand.

This exposure records alluviation, which ended sometime before $1.7 \mathrm{ka}$, and was followed by an interval of peat formation associated with probable eolian activity.

\section{Exposure A-3}

An exposure along the north bank of Atigun River $0.5 \mathrm{~km}$ east of Galbraith Lake's outlet stream exhibits near-horizontal beds of sand and silty fine sand that are transitional upward into sandy peat with scattered twigs (fig. 15). Wood within this peat and near its upper contact dates $\mathbf{2 , 5 1 0} \pm \mathbf{1 1 0}$ yr B.P. and 2,245 $\pm \mathbf{1 2 0}$

\section{Exposure A-2}

A bluff along the east side of Atigun River $2.5 \mathrm{~km}$ south of Galbraith Lake (beyond the south margin of the map sheet) intersects a field of sand dunes on the valley floor. The bluff face exposes mainly silt, silty fine sand, and some silty clay, in near-horizontal beds that are interstratified with thinner peat layers (fig. 13). A peat bed $11.9 \mathrm{~m}$ above the base of the deposit is dated at $\mathbf{2 , 0 0 0}$ \pm 80 yr B.P. Weakly bedded sand containing shale chips forms an eolian deposit $3.8 \mathrm{~m}$ thick above the near-horizontal beds. The bluff is capped by a 1-m-thick deposit of sandy peat above peaty sand.

Alluviation of basin-filling deposits to a height of $17.3 \mathrm{~m}$ above modern river level apparently took place about $2.0 \mathrm{ka}$. Absence of soils and weathering horizons within the section indicates that alluviation, like that at exposure A-1, must have been rapid. A subsequent period of eolian dune-building was succeeded by stabilization of the sand and formation of the peaty bluff cap.

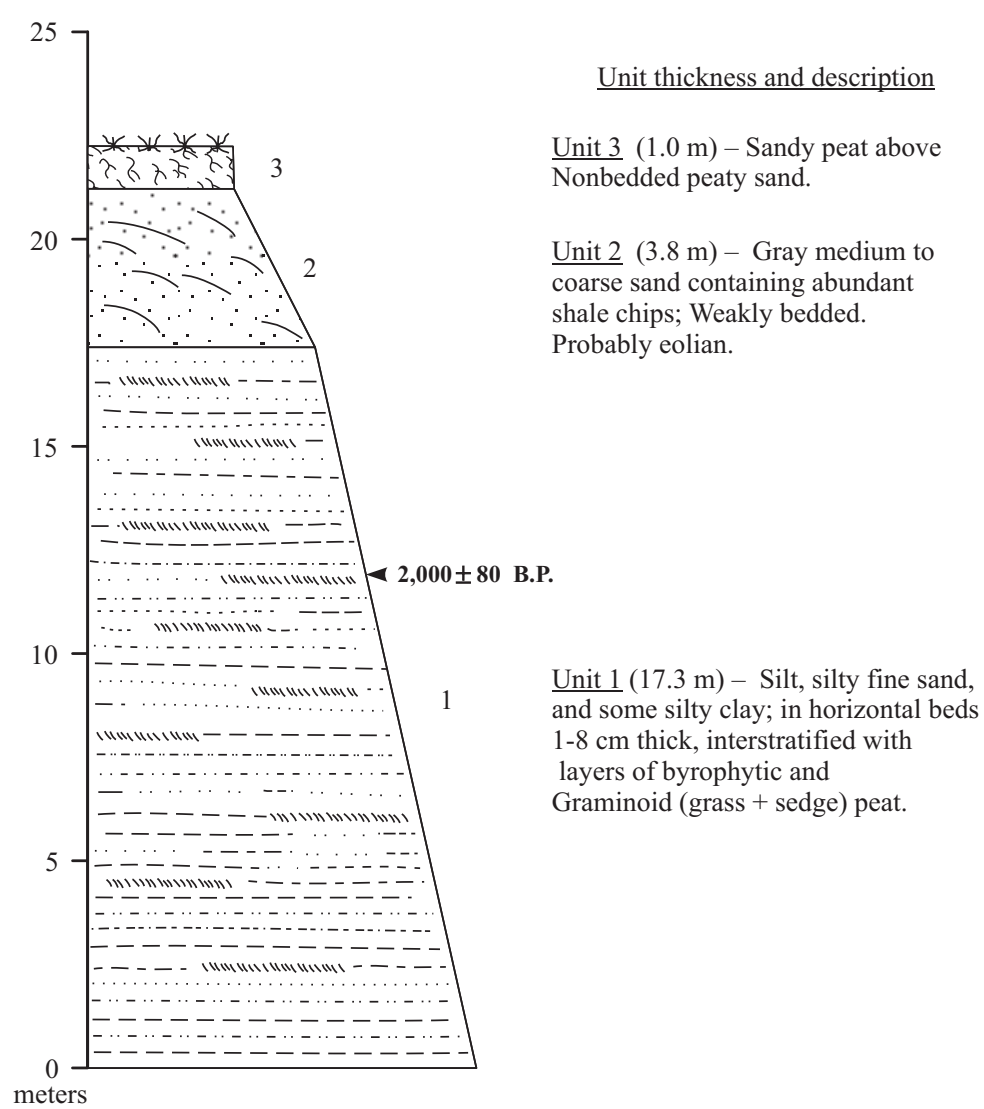

Figure 13. Exposure A-2, east side Atigun River $2.5 \mathrm{~km}$ south of Galbraith Lake (1.8 $\mathrm{km}$ beyond south margin of map). 
yr B.P., respectively. The peat is capped by dune sand that contains wood dated at $740 \pm 100$ yr. B.P.

This deposit records a period of stability and low river level that began sometime before $2.5 \mathrm{ka}$ and evidently continued for at least several hundred years. However, the upper surface of the peat could have been eroded by wind or river, and original accumulation might have continued for some time after $2.2 \mathrm{ka}$.

\section{'Mosquito Lake' Test Pit (Kunz, 1977)}

During excavations in 1974 at the 'Mosquito Lake' (informal name) archeological site, a test pit was dug down to permafrost by Michael L. Kunz. The pit (designated "ML" on sheet 1) is located about $0.2 \mathrm{~km}$ north of Mosquito Lake and $0.4 \mathrm{~km}$ east-southeast of the mouth of the Galbraith Lake outlet stream. Its height above Atigun River is uncertain, but probably is within about $50 \mathrm{ft}(15 \mathrm{~m})$ of modern river level. The pit penetrated a deposit of eolian sand $95 \mathrm{~cm}$ thick, and continued for 15 cm into 'marsh, swamp, or river edge' sediments before encountering permafrost. 'Organic material' (a paleosol?)

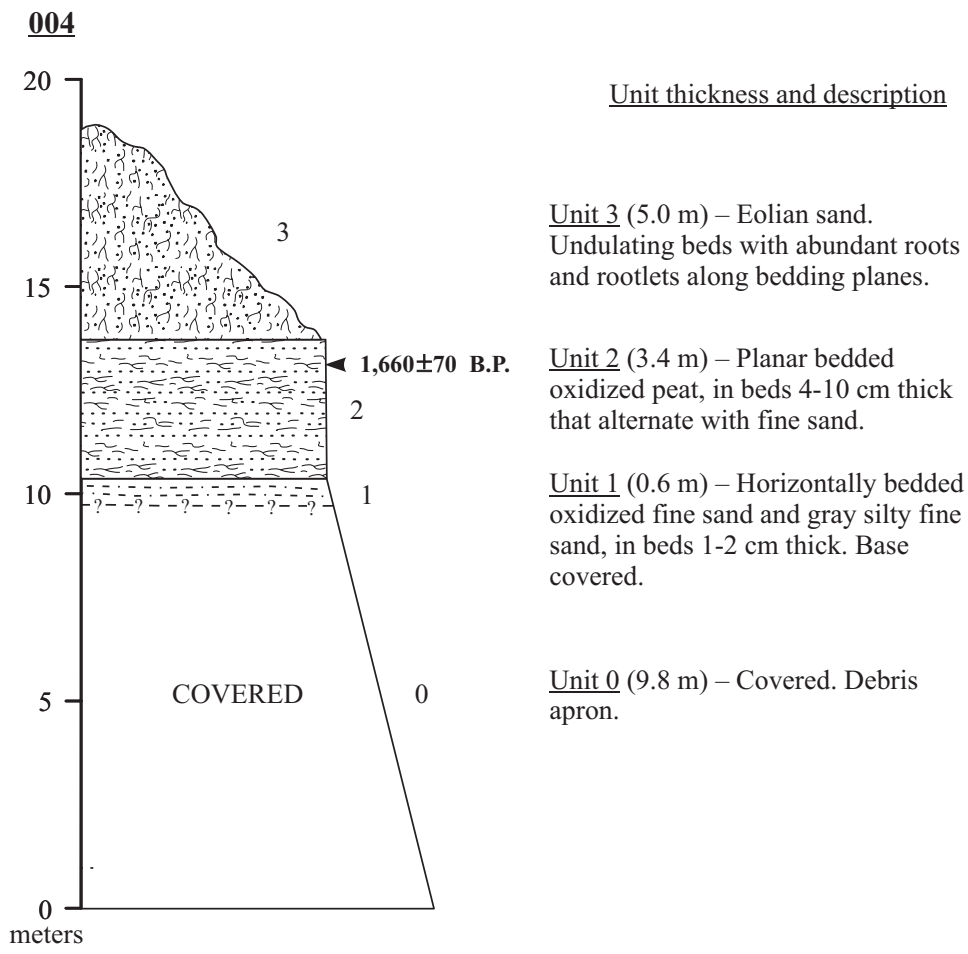

Figure 14. Bluff exposure, north side Galbraith Lake outlet stream $0.8 \mathrm{~km}$ southeast of lake (sample 004).

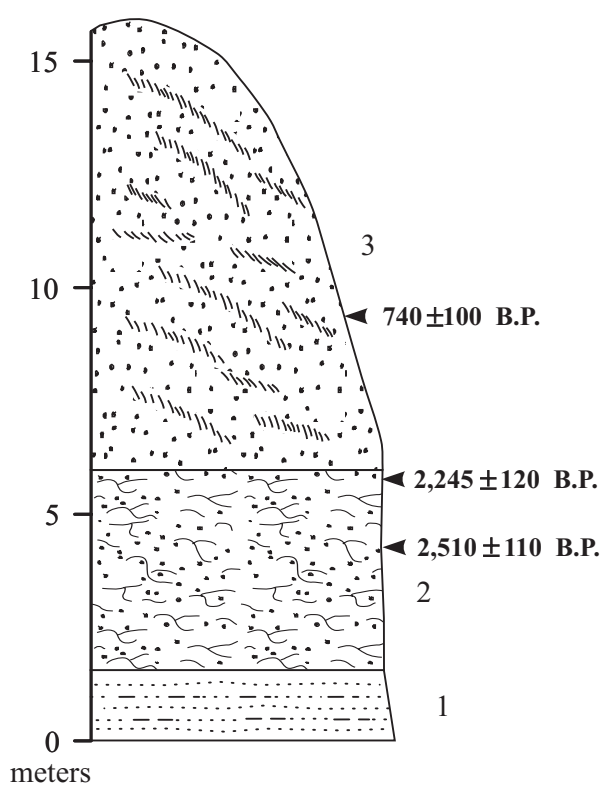

$\underline{\text { Unit thickness and description }}$

Unit $3(5-10 \mathrm{~m})$ - Dune sand. Dominantly medium sand to granules, with shale chips abundant in coarse sand to granule range. Upper $2 \mathrm{~m}$ mainly peaty fine to medium sand. Irregular upper surface with dunal morphology.

Figure 15. Exposure A-3, north bank Atigun River $0.5 \mathrm{~km}$ downstream (east) from mouth of Galbraith Lake outlet stream. From Hamilton, $1979 \mathrm{~b}$. 
at the contact between the sand and underlying sediment is dated at $\mathbf{4 , 8 3 0} \pm \mathbf{1 5 5} \mathbf{~ y r}$ B.P.

Because of its relatively large counting error, the radiocarbon age from 'Mosquito Lake' is considered to overlap the 4,630 and 4,740 yr B.P. ages from the topmost basin-filling deposits at exposure A-1. The concordance of these ages appears to confirm rapid basin-wide alluviation across the floor of Atigun valley.

\section{SAGAVANIRKTOK RIVER VALLEY}

Eleven radiocarbon samples were collected from four localities within or near the limited section of the Sagavanirktok valley floor that lies within the map area. Most were taken in 1975 during fieldwork supported by the U.S. Geological Survey.

\section{Exposure S-1}

A south-facing river bluff $24.5 \mathrm{~m}$ high is situated at the apex of a south-facing meander bend along the Sagavanirktok River $3.5 \mathrm{~km}$ upstream from the mouth of Atigun River. The bluff exposes basin-filling sand and related deposits (fig. 16A). Lower units contain fine gravel and locally are cross-bedded. The deposit fines upward and becomes increasingly organic. Two nearly identical ages on willow roots in the lower part of the exposure indicate rapid alluviation about 12,800 yr B.P. Slower accumulation of peaty marsh deposits continued until sometime after about $11,360 \pm 170 \mathrm{yr}$ B.P., and about $4 \mathrm{~m}$ of sandy peat accumulated between about $8,930 \pm 140$ and $\mathbf{5 , 4 5 5} \pm \mathbf{1 0 5} \mathrm{yr}$ B.P. The bluff is capped by sod above organic-rich silt that may represent a buried tundra soil.

The basin-filling deposit is largely fluvial in character, and therefore must have formed when the Sagavanirktok River was blocked by readvance of the Atigun piedmont lobe during late Itkillik II time. This blockage had begun by about $12.8 \mathrm{ka}$, and the alluviating river evidently remained at a high level until after $11.4 \mathrm{ka}$, when sandy and peaty interbeds were still forming on a probable marshy floodplain. Active glacier ice probably continued to block the Sagavanirktok River during the entire 1,400-year interval of alluviation. Subsequent downcutting began sometime prior to $8.9 \mathrm{ka}$, when peat became dominant and sandy interbeds uncommon.

\section{Exposure S-2}

Similar basin-filling sand with in situ willow roots is exposed close to modern river level along the west side of Sagavanirktok River $10 \mathrm{~km}$ upvalley from exposure S-1 (fig. 16B). The basin-filling deposit is dated at $11,760 \pm 200 \mathrm{yr}$ B.P., and is concordant with the interval of glacier blockage inferred from exposure S-1.
Absence of gravel in the deposit shows that outwash deposition from receding glaciers near the head of the Sagavanirktok valley either had ceased by about $11.8 \mathrm{ka}$ or that outwash was unable to extend very far downvalley into the sand-filled depositional basin.

The two younger radiocarbon ages from exposure S-2 are not discussed here and are not included in table 3 . This exposure is situated $4 \mathrm{~km}$ beyond the southeast corner of the map area and its capping eolian deposits may be of only local significance.

\section{Exposure S-3}

A 12-m-high bluff along the west bank of Sagavanirktok River $6.3 \mathrm{~km}$ upvalley from the mouth of Atigun River is located near the toe of an alluvial fan that extends eastward across the western part of the valley floor. The bluff exhibits interbedded silty and gravelly alluvium with diverse clast lithologies that extends to about $11 \mathrm{~m}$ above the present-day river and is capped by eolian sand with peat (fig. 17). Absence of buried soils, peaty horizons, and weathering features indicates that alluviation probably was rapid; and the two virtually identical radiocarbon ages of 5,270 \pm 105 and $5,310 \pm 100 \mathrm{yr}$ B.P. on detrital plant remains and wood fragments at 8 and $10 \mathrm{~m}$ height, respectively, confirm rapid deposition through the upper part of the section. Incision of the deposit probably began shortly after about $5.3 \mathrm{ka}$.

The alluvial record from exposure S-3 is consistent with that of S-1, which records downcutting toward modern river level sometime prior to $5.5 \mathrm{ka}$. Roundness and sorting of the gravel beds and their diverse clast lithologies indicate deposition by the Sagavanirktok River rather than the local alluvial fan, but fan progradation across the valley floor may have provided a local base level that induced the river to alluviate.

\section{Sample 019}

A cutbank along the west side of Sagavanirktok River $31 \mathrm{~km}$ north of the mouth of Atigun River is located at the upstream end of an extensive deposit of till and ice-contact stratified drift that forms an irregular surface about $50 \mathrm{~m}$ above river level. The cutbank yields a 9-m exposure into the base of a terrace-like deposit 15-20 m high whose upper face is concealed by slumped and vegetated colluvium (fig. 18). Bedrock near river level is overlain by cobble-rich gravel that has a lag deposit of large cobbles along its upper contact. An overlying paleosol, which contains thin beds of humic matter dated at $\mathbf{7 , 0 3 0} \pm \mathbf{1 0 0} \mathbf{~ y r}$ B.P., has a channeled upper surface. It is overlain by near-horizontal beds of inorganic sand and silty fine sand, which contain some granules near their base. 


\section{A. Exposure S-1}

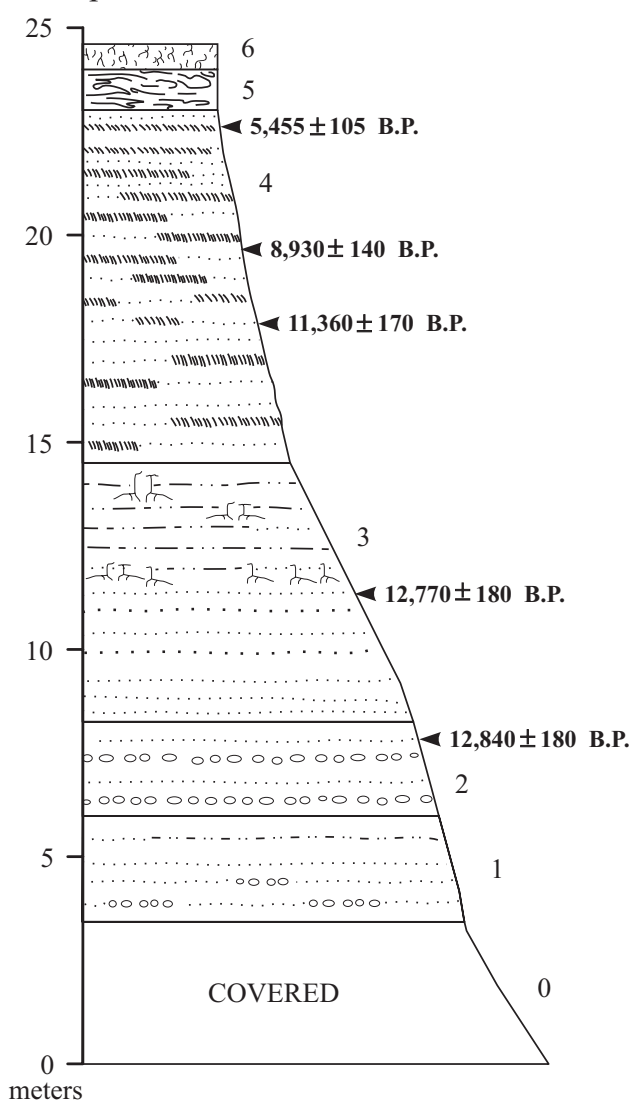

Unit thickness and description

Unit $6(.5 \mathrm{~m})-$ Surface sod and underlying organic mat.

Unit $5(1.0 \mathrm{~m})$ - Dark grayish-brown (10YR 4/2) organic silt. Some intermixed organic matter; some iron oxide staining; prismatic structure near upper contact.

$\underline{\text { Unit } 4}(8.7 \mathrm{~m})$ - Sandy peat and peaty sand; horizontally bedded. Peat mainly matted plant roots with twigs. Sand and sandy peat alternate near base; peat becomes dominant upward.

Unit $3(6.0 \mathrm{~m})$ - Dark gray sand, fining upward. Forms near-horizontal beds 3$5 \mathrm{~cm}$ thick, with plant remains along bedding planes. Concentration of willow roots in middle of unit.

Unit $2(2.4 \mathrm{~m})$ - Gray sand and fine (granule-small pebble) gravel, alternating in near-horizontal beds $6-12 \mathrm{~cm}$ thick. Locally cross-bedded.

Unit $1(2.4 \mathrm{~m})$ - Gray fine to coarse sand, fining upward, with faint nearhorizontal bedding. Lower $1.2 \mathrm{~m}$ contains layers and lenses of granules and rare small pebbles; upper $1.2 \mathrm{~m}$ contains very thin clayey interbeds.

$\underline{\text { Unit } 0}(3.6 \mathrm{~m})-$ Covered. Debris apron at slope base.

\author{
$\underline{\text { Unit thickness and description }}$
}

Unit 4 (3.8) - Weakly bedded medium to silty fine sand, with abundant roots and other plant fragments. Some beds stained by iron oxides. Cultural horizon at $1.3 \mathrm{~m}$ depth. Probably eolian.

$\underline{\text { Unit } 3}(0.5 \mathrm{~m})-$ Mottled fine sand with abundant grass remains. Probably eolian; possibly deposited at margin of active river flood plain. Gradual transition to unit 4.

$\underline{\text { Unit } 2}(0.5 \mathrm{~m})$ - Clayey, silty fine sand, with clay layers in middle of unit. Cutand-fill structures present, with fillings generally clay-rich. Probably marsh or shallow pond on intermittently active flood plain. Sharp transition to unit 3 .

Unit $1(2.5 \mathrm{~m})-$ Gray sand. Weak, near-horizontal bedding, with beds $1-5 \mathrm{~cm}$ thick. Contains roots and other plant fragments. Probably overbank deposits of aggrading flood plain. Gradual transition to unit 2.

$\underline{\text { Unit } 0}(0.5 \mathrm{~m})$ - Boulder-cobble lag conglomerate. Probably deposited by modern river.

Figure 16. Bluff exposures with radiocarbon-dated deposits of late Itkillik II age, upper Sagavanirktok River valley (Hamilton, 1979b).

A. Exposure S-1, north side Sagavanirktok River $3 \mathrm{~km}$ above mouth of Atigun River.

B. Exposure S-2, west side Sagavanirktok River $13 \mathrm{~km}$ above mouth of Atigun River. 
The cobble gravel probably is associated with the outwash train of the late Itkillik II readvance, which extends down the east side of the Sagavanirktok valley floor for at least $16 \mathrm{~km}$ beyond the front of the piedmont lobe that issued from Atigun Gorge (sheet 1). The paleosol, which probably is a buried tundra soil, formed after glacier retreat had allowed downcutting by the Sagavanirktok River and abandonment of its outwash train. Incision by the Sagavanirktok River must also have taken place to isolate the outwash surface from further inundation during flood periods. However, the channeled surface of the paleosol and fine gravel near the base of the overlying sand indicates that flowing water again covered the site sometime after about $7 \mathrm{ka}$. The bedded sand above the paleosol appears to be an alluvial basin-filling deposit, but the cause of its aggradation is uncertain.

\section{OTHER DATED LOCALITIES Sample 018B}

A small thaw pond about $15 \mathrm{~km}$ north-northeast of Toolik Lake is situated on the floor of a pass through Imnavait Mountain. Erosion along the northeast shore of the pond has exposed the toe of a smoothly graded solifluction slope that extends from the west flank of the mountain down to the lakeshore. An exposure $4 \mathrm{~m}$ high consists dominantly of structureless dark gray to dark brown silt that contains a bed of bryophytic peat at 70 to $76 \mathrm{~cm}$ depth, which is dated at $\mathbf{2 , 4 0 0} \pm \mathbf{7 0}$ yr B.P. (fig. 19). Sod and black humic silt cap the exposure.

The structureless silt probably was deposited initially as loess, then was transported downslope by solifluction to the floor of the pass. The peat represents a significant hiatus in this solifluction activity. It may reflect an interval of milder climate, perhaps accompanied by decreased influx of eolian silt.

\section{Exposure A-4}

The head of a large active retrogressive thaw slump (Burn and Friele, 1989) situated about $4.5 \mathrm{~km}$ northwest of Galbraith Lake exposes gray stony silt of probable glaciolacustrine origin. A discontinuous bed of peat and organic silt that overlies the glacial deposit $\underline{\text { Unit thickness and description }}$

Unit $2(0.5-1.0 \mathrm{~m})-$ Sand, peat, and sandy peat. Sand dominantly eolian.

Unit 1 (11 m) - Interbedded silt and gravel. Rounded to subrounded, fairly well sorted pebbles and small cobbles of diverse lithologies in matrix of shale chips in medium sand to granule range. Interbedded with finely laminated clayey silt to silty fine sand in beds $0.3-0.5 \mathrm{~mm}$ thick containing detrital twigs and matted plant remains along bedding planes. Probably channel gravel and overbank deposits.

Figure 17. Exposure S-3, west side Sagavanirktok River $6 \mathrm{~km}$ above mouth of Atigun River. From Hamilton, $1979 b$.

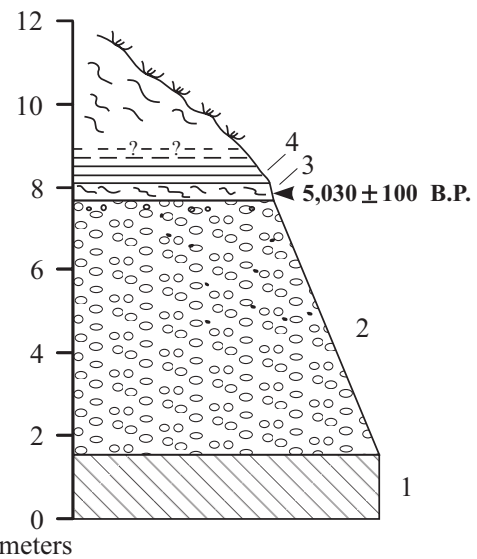

sandstone beds. Base concealed. finely divided organic matter.

\section{Unit thickness and description}

Unit $4(0.8+\mathrm{m})-$ Sand. Medium sand and silty fine sand, in near-horizontal beds $4-14 \mathrm{~cm}$ thick. Some granules near base. Upper part slumped and vegetated.

Unit $3(0.4 \mathrm{~m})$ - Paleosol. Oxidized, silty, fine sand, with thin layers and lenses of

Unit $2(6.3 \mathrm{~m})-$ Gravel. Subrounded clasts to cobble size in sandy matrix. Coarse cobble lag at upper surface.

Unit $1(1.5+)-$ Bedrock. Black shale with Figure 18. Bank exposure, west side Sagavanirktok River $31 \mathrm{~km}$ north of mouth of Atigun River (sample 019).

is dated at $\mathbf{1 , 8 5 0} \pm \mathbf{8 5} \mathbf{y r}$ B.P. (fig. 20). The peat, which represents an interval of surface stability and nondeposition, was buried by mottled silt that probably formed when a solifluction sheet overrode the site.

\section{DISCUSSION AND CONCLUSIONS}

Six radiocarbon ages from the Sagavanirktok and Itkillik River valleys provide age control on the late Itkillik II readvance and associated latest Pleistocene river history. Rapid alluviation about $12.8 \mathrm{ka}$ at exposure S-1 must have occurred when the advancing Atigun piedmont lobe initially crossed the Sagavanirktok valley floor. Alluviation continued at slower rates until after $11.8 \mathrm{ka}$ at exposure S-2, $10 \mathrm{~km}$ upvalley, and until about $11.4 \mathrm{ka}$ at S-1. A date of $11.3 \mathrm{ka}$ on detrital wood in Itkillik valley near the range front indicates that glacier ice probably had receded into the Brooks Range by that 
time. However, the wood may have been redeposited from older sediments and therefore provides only a maximum age on local river aggradation. Farther down Itkillik valley, an age of $10.1 \mathrm{ka}$ on a paleosol within the outer Itkillik II end moraines, if valid, should provide a minimum limiting age on river downcutting below $9.5 \mathrm{~m}$ height through this moraine belt. The downcutting took place during a time of moderating climate following the Itkillik II readvance (Mann and Hamilton, 1995; Mann and others, 1998), which may have accelerated meltout of stagnant glacier ice within the moraines.

The early Holocene at exposure S-1 was an interval of slow accretion of peaty sand on a marshy surface 19-23 m above modern river level. Absence of overbank deposits indicates that the river had abandoned that surface by $8.9 \mathrm{ka}$ and was downcutting toward its modern level. A comparable age of $7.0 \mathrm{ka}$ beyond the downvalley flank of the Atigun moraine (sample 019) demonstrates that downcutting through the outwash train from the Atigun lobe had begun before that time.

A concordant set of radiocarbon ages from Atigun valley exposure A-1 shows rapid alluviation of basinfilling deposits to a height of about $15 \mathrm{~m}$ above modern river level between about 5.0 and $4.8 \mathrm{ka}$. An identical age ( $4.8 \mathrm{ka}$ ) from the Mosquito Lake site confirms that general filling of the Atigun valley floor south of Galbraith Lake terminated at about this time. The basin-filling deposits that buried the paleosol at locality 019 in the Sagavanirktok valley sometime after $7.0 \mathrm{ka}$ could possibly have been deposited in phase with alluviation in Atigun valley. At locality $18 \mathrm{~A}$ within Itkillik valley, a buried tundra soil formed above alluvium about $5.7 \mathrm{ka}$. This site occurs within the depositional basin confined between moraine belts of
Unit thickness and description

Unit $4(15 \mathrm{~cm})-$ Sod. Above black humic silt. Unit $3(55 \mathrm{~cm})-$ Silt. Same as Unit 1.

Unit $2(6 \mathrm{~cm})-$ Peat. Bryophytic.

Unit $1(324+\mathrm{cm})-$ Silt. Dark gray $(5 Y R 4 / 1)$ to dark brown (7.5YR 3/2). Extends below lake level.
Itkillik II maximum advances and the late Itkillik II readvances. No basin-filling deposits formed during or after mid-Holocene time in this segment of the valley.

Rapid alluviation to a level about $11 \mathrm{~m}$ above modern river occurred about $5.3 \mathrm{ka}$ at exposure S-3 in the Sagavanirktok valley. This age is nearly identical to that of the youngest sandy peat deposits at S-1, a short distance downvalley, which probably reflect influx of sand from the alluviating valley floor. Deposition of thick organic silt, interpreted as a buried tundra soil, began shortly afterward at S-1, probably after influx of eolian sand had ceased owing to river incision and establishment of protective vegetation cover on the sandy basin floor. Peat that underlies eolian deposits at locality I-1 in Itkillik valley has a radiocarbon age of $4.2 \mathrm{ka}$, but the significance of this age determination is uncertain.

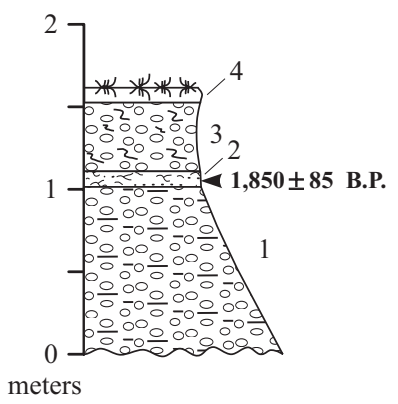

Unit $4(7 \mathrm{~cm})-$ Organic mat.

Unit Thickness and Description

Unit $3(39 \mathrm{~cm})$ - Stony clayey silt, mottled brown $(7.5 \mathrm{YR} 4 / 4)$ to dark grey $(5 \mathrm{Y} 4 / 1)$.

Unit $2(0-10 \mathrm{~cm})-$ Dark brown $(7.5 \mathrm{YR} 3 / 2)$ peat, grading laterally into organic silt with thin $(1 \mathrm{~cm})$ peat cap.

Unit $1(100+\mathrm{cm})-$ Dark gray stony silt, containing striated stones up to $1.5 \mathrm{~m}$ diameter. Contains excess ice in lenses and layers up to $0.5 \mathrm{~cm}$ thick. Underlain by massive ground ice more than $1 \mathrm{~m}$ thick. Extends below lake level.

Figure 20. Exposure A-4, headwall of active earthflow 4.5 km northwest of Galbraith Lake. From Hamilton, $1979 b$. 
The late Holocene (beginning about 3.5-4.0 ka) was a period of intermittent cirque-glacier expansion within the Brooks Range and alluviation of cirque-headed river valleys along the range's north flank (Hamilton, 1981; Ellis and Calkin, 1984). Several sites in the map area reflect aspects of late Holocene glacial and climatic history. In the clearest example, radiocarbon age determinations from peat beds at four localities suggest an interval of milder climate about 2.9-2.2 ka, a period when cirque glaciers appear to have been in generally retracted positions (Ellis and Calkin, 1984). In Itkillik valley, a thick peat bed with a basal age of $2.9 \mathrm{ka}$ (sample 008) close to modern river level represents a period of stability with little eolian deposition and absence of river alluviation. The time span represented by this $3.1-\mathrm{m}$ thick peat bed is uncertain, but peat formation almost certainly continued after $2.5 \mathrm{ka}$, when another peat bed that locally extends below modern river level was forming a short distance upvalley at locality I-2. Another thick peat deposit near river level is situated at Atigun River exposure A-3. The upper part of this peat has radiocarbon ages of 2.5 to $2.2 \mathrm{ka}$. A comparable age of 2.4 ka was obtained on peat (sample $018 \mathrm{~B}$ ) that accumulated during a hiatus in solifluction activity on the flank of Imnavait Mountain.

A single radiocarbon age of $2.0 \mathrm{ka}$ at exposure A-2 suggests that Atigun River again alluviated rapidly to a height of about $17 \mathrm{~m}$ at that time. Tenuous support for that age is provided by peat dated at $1.7 \mathrm{ka}$ along Galbraith Lake's outlet stream. This age places a minimum limit on basin-filling to at least $10 \mathrm{~m}$ height and a maximum age limit on subsequent accumulation of thick eolian dune sand. Eolian activity may have scoured the basin-filling sand deposits from some greater height down to its present $10-\mathrm{m}$ level.

A later interval of peat formation near modern river level near the range front in Itkillik valley (exposure I3 ) is dated at about $1.3 \mathrm{ka}$, and was followed by about $500 \mathrm{yr}$ of alluviation to a terrace level about $6.5 \mathrm{~m}$ above the present-day river. The river subsequently incised the alluvium, and had cut down to a level near or beneath that of the present day by about 400 years ago. Subsequent alluviation to a $4.1-\mathrm{m}$ terrace level took place during a time of widespread glacial advances that is termed the Little Ice Age and is widely recognized in Alaska (Calkin, 1988; Calkin and Wiles, 1991).

The radiocarbon record from the map area shows some consistent climate-related patterns, but also some puzzling irregularities that may be independent of climate control. For example, rapid basin-filling across the floor of Atigun valley took place about $5.0-4.8 \mathrm{ka}$, and again possibly about $2.0 \mathrm{ka}$, when little alluviation was taking place in adjoining valleys. Such rapid accretion of sandy deposits in a single valley is best explained by rapid and localized base-level rise. At least one large (unit Is?) landslide must have occurred in Atigun Gorge as the river cut down through glacial deposits and perhaps bedrock following latest Pleistocene deglaciation. Such landslides could have repeatedly dammed Atigun River. Other apparent inconsistencies in the radiocarbon record are related to individual depositional basins that formed behind separate moraine belts, such as those along the floor of Itkillik River valley. Histories of alluviation and downcutting may differ between basins, even within the same drainage system. Large tributary fans such as that formed by Itikmalak River also tend to subdivide depositional basins into separate compartments that may react individually to climatic fluctuations, cirque-glacier advances, tectonism, or other environmental controls.

\section{ACKNOWLEDGMENTS}

My initial surficial geologic mapping of the study area was supported by the Trans-Alaska Pipeline System (which later became Alyeska Pipeline Service Company) in 1969-72 and by the U.S. Geological Survey (USGS) in 1975-76. Robert M. Thorson provided capable field and office assistance during the USGS mapping project. The more detailed subsequent mapping utilized in this report was supported in 1996-97 by D.A. (Skip) Walker through the University of Colorado's Institute of Arctic and Alpine Research and in 2001 by the Alaska Department of Natural Resources (DNR) Division of Geological \& Geophysical Surveys (DGGS). Cartographic and GIS support were provided by James Anderson at the University of Colorado; Andrew Balser at the Alaska Geobotany Center, University of Alaska Fairbanks; and Simone Montayne and Ellen E. Harris at the Alaska DNR/DGGS. Earlier drafts of the map and report were reviewed by Skip Walker, Ellen E. Harris, Darrell S. Kaufman, and Rodney A. Combellick. Their thoughtful and insightful comments helped greatly to eliminate errors and increase the readability of this map and report.

I am grateful to the USGS for providing, through its Emeritus program, office facilities and other support essential for compilation of the map and preparation of supporting text.

\section{REFERENCES CITED}

Alexander, H.L., 1987, Putu-A fluted point site in Alaska: Burnaby, British Columbia, Simon Fraser University, Archaeology Department Publication No. 17,47 p.

Astakhov, V.I., 1992, The last glaciation in West Siberia: Sveriges Geologiska Undersokning, Ser. Ca 81, p. $21-30$. 
Astakhov, V.I., Kaplyanskaya, F.A., and Tarnogradsky, V.D., 1996, Pleistocene permafrost of West Siberia as a deformable glacier bed: Permafrost and Periglacial Processes, v. 7, p. 165-191.

Black, R.F., 1976, Periglacial features indicative of permafrost: Ice and soil wedges: Quaternary Research, v. 6, p. 3-26.

Brosgé, W.P., Reiser, H.N, Dutro, J.T., Jr., and Detterman, R.L., 1979, Bedrock geologic map of the Philip Smith Mountains quadrangle, Alaska: U.S. Geological Survey Miscellaneous Field Investigations Map MF-879-B, scale 1:250,000.

Brown, J., Ferrians, O.J., Jr., Heginbottom, J.A., and Melnikov, E.S., 1997, Circum-Arctic map of permafrost and ground-ice conditions: U.S. Geological Survey Circum-Pacific Map Series CP45, scale 1:10,000,000, 1 sheet.

Burn, C.R., and Friele, P.A., 1989, Geomorphology, vegetation succession, soil characteristics and permafrost in retrogressive thaw slumps near Mayo, Yukon Territory: Arctic, v. 42, p. 31-40.

Calkin, P.E., 1988, Holocene glaciation of Alaska (and adjoining Yukon Territory): Quaternary Science Reviews, v. 7, p. 159-184.

Calkin, P.E., and Wiles, G.C., 1991, Little Ice Age glaciation in Alaska - a record of global climatic change, in Weller, Gunter, Wilson, C.L., and Severin, B.A.B., eds., International Conference on the Role of the Polar Regions in Global Change, University of Alaska Fairbanks, June 1990: Fairbanks, University of Alaska, v. II, p. 617-625.

Detterman, R.L., 1953, Sagavanirktok-Anaktuvuk region, northern Alaska, in Péwé, T.L., and others, Multiple glaciation in Alaska: U.S. Geological Survey Circular 289, p. 11-12.

Detterman, R.L., Bowsher, A.L., and Dutro, J.T., Jr., 1958, Glaciation on the Arctic Slope of the Brooks Range, northern Alaska: Arctic, v. 11, p. 43-61.

Dixon, E.J., Jr., 1975, The Gallagher Flint Station, an early man site on the North Slope, arctic Alaska, and its role in relation to the Bering Land Bridge: Arctic Anthropology, v. 7, p. 68-75.

Ellis, J.M., and Calkin, P.E., 1984, Chronology of Holocene glaciation, central Brooks Range, Alaska: Geological Society of America Bulletin, v. 95, p. 897-912.

Ferguson, D.E., 1997, Revised temporal assessment of a proposed Paleoarctic site in the Sagavanirktok valley, northern Alaska: Current Research in the Pleistocene, v. 14, p. 24-26.

Ferrians, O.J., Jr., 1965, Permafrost map of Alaska: U.S. Geological Survey Miscellaneous Geologic Investigations Map I-445, scale 1:2,500,000, 1 sheet.
Fujino, K., Sato, S., Matsuda, K., Sasa, G., Shimizu, O., and Kato, K., 1988, Characteristics of the massive ground ice body in the western Canadian Arctic, in Senneset, Kaare, ed., Proceedings of the Fifth International Conference on Permafrost, Trondheim, Norway, August 1988, v. 1: Trondheim, Tapir Publishers, p. 143-147.

Grantz, Arthur, May, S.D., and Hart, P.E., 1994, Geology of the Arctic continental margin of Alaska, in Plafker, George, and Berg, H.C., eds., The geology of Alaska: Geological Society of America, The Geology of North America, v. G-1, p. 17-48.

Hamilton, T.D., 1978, Surficial geologic map of the Philip Smith Mountains quadrangle, Alaska: U.S. Geological Survey Miscellaneous Field Studies Map MF-879-A, 1 sheet, scale 1:250,000.

1979a, Surficial geologic map of the Chandler Lake quadrangle, Alaska: U.S. Geological Survey Miscellaneous Field Studies Map MF-1121, 1 sheet, scale 1:250,000.

-1979b, Radiocarbon dates and Quaternary stratigraphic sections, Philip Smith Mountains quadrangle, Alaska: U.S. Geological Survey Openfile Report 79-866, 44 p.

1980. Surficial geologic map of the Killik River quadrangle, Alaska: U.S. Geological Survey Miscellaneous Field Studies Map MF-1234, 1 sheet, scale 1:250,000.

1981, Episodic Holocene alluviation in the central Brooks Range-chronology, correlations, and climatic implications, in Albert, N.R.D., and Hudson, Travis, eds., United States Geological Survey in Alaska-Accomplishments during 1979: U.S. Geological Survey Circular 823-B, p. B21B24.

Hamilton, T.D., 1982a, Relict Pleistocene glacier ice in northern Alaska, in Abstracts, Institute of Arctic and Alpine Research, 11th Annual Arctic Workshop, March 1982: Boulder, University of Colorado, p. 25-26.

1982b, A late Pleistocene glacial chronology for the southern Brooks Range-stratigraphic record and regional significance: Geological Society of America Bulletin, v. 93, p. 700-716.

1986, Late Cenozoic glaciation of the central Brooks Range, in Hamilton, T.D., Reed, K.M., and Thorson, R.M., eds., Glaciation in Alaska-the geological record: Anchorage, Alaska Geological Society, p. 9-49.

1994, Late Cenozoic glaciation of Alaska, in Plafker, George, and Berg, H.C., eds., The geology of Alaska: Boulder, CO, Geological Society of America, The Geology of North America, v. G-1, p. 813-844. 
Hamilton, T.D., 1996, Late Pleistocene stratigraphic sections from northern Alaska, in West, F.H., ed., American beginnings - the prehistory and palaeoecology of Beringia: Chicago, IL, University of Chicago Press, p. 21-34.

Hamilton, T.D., and Goebel, Ted, 1999, Late Pleistocene peopling of Alaska, in Bonnichsen, Robson, and Turnmire, K.L., eds., Ice Age peoples of North America-Environments, origins, and adaptations: Corvallis, Oregon State University Press, p. 156199.

Hamilton, T.D., and Porter, S.C., 1975, Itkillik glaciation in the Brooks Range, northern Alaska: Quaternary Research, v. 5, p. 471-497.

Houmark-Nielsen, Michael, Hansen, Louise, Jorgensen, M.E., and Kronborg, Christian, 1994, Stratigraphy of a Late Pleistocene ice-cored moraine at Kap Herschell, northeast Greenland: Boreas, v. 23 (PONAM volume), p. 505-512.

Jorgenson, M.T., 1984, The response of vegetation to landscape evolution on glacial till near Toolik Lake, Alaska, in Laban, V.J., and Kerr, C.I., eds., Inventorying forest and other vegetation of the high latitude and high altitude regions; Proceedings of an international symposium: Society of American Foresters Technical Conference, Fairbanks, Alaska, p. 134-141.

Kreig, R.A., and Reger, R.D., 1982, Air-photo analysis and summary of landform soil properties along the route of the Trans-Alaska Pipeline System: Alaska Department of Natural Resources, Division of Geological \& Geophysical Surveys Geologic Report $66,149 \mathrm{p}$.

Kunz, M.L., 1977, Mosquito Lake site (PSM-049), in Cook, J.P., ed., Pipeline archeology_Final report, archeological investigation along the Trans-Alaska Pipeline: Fairbanks, University of Alaska Institute of Arctic Biology, p. 747-982.

Mann, D.H., Crowell, A.L., Hamilton, T.D., and Finney, B.P., 1998, Holocene geologic and climatic history around the Gulf of Alaska: Arctic Anthropology, v. 35 , p. 112-131.

Mann, D.H., and Hamilton, T.D., 1995, Late Pleistocene and Holocene paleoenvironments of the north Pacific coast: Quaternary Science Reviews, v. 14, p. 449-471.
Munroe, J.S., and Bockheim, J.G., 2001, Soil development in low-arctic tundra of the northern Brooks Range, Alaska, U.S.A.: Arctic, Antarctic, and Alpine Research, v. 33, p. 78-87.

Porter, S.C., 1964, Late Pleistocene glacial chronology of the north-central Brooks Range, Alaska: American Journal of Science, v. 262, p. 446-460.

Porter, S.C., and Denton, G.H., 1967, Chronology of Neoglaciation in the North American Cordillera: American Journal of Science, v. 265, p. 177-210.

Reanier, R.E., 1995, The antiquity of Paleoindian materials in northern Alaska: Arctic Anthropology, v. 32, p. 31-50.

Richmond, G.M., and Fullerton, D.S., 1986, Summation of Quaternary glaciations in the United States of America, in Richmond, G.M., and Fullerton, D.S., eds., Quaternary glaciations in the United States of America: Quaternary Science Reviews, v. 5 (Quaternary Glaciations in the Northern Hemisphere), p. 183-196.

St. Onge, D.A., and McMartin, Isabelle, 1989, Geomorphology of arctic glacial landforms and buried glacier ice: Geological Association of Canada, Program with Abstracts, v. 14, p. A131.

Vaikmae, Rein, Michel, F.A., and Solomatin, V.I., 1993, Morphology, stratigraphy, and oxygen isotope composition of fossil glacier ice at Ledyanaya Gora, northwest Siberia, Russia: Boreas, v. 22, p. 205213.

Walker, D.A., Short, S.K., Andrews, J.T., and Webber, P.J., 1981, Late Holocene pollen and present-day vegetation, Prudhoe Bay and Atigun River, Alaskan North Slope: Arctic and Alpine Research, v. 13, p. 153-172.

Walker, D.A., and Walker, M.D., 1996, Terrain and vegetation of the Imnavait Creek watershed, in Reynolds, J.F., and Tenhunen, J.D., eds., Landscape function and disturbance in arctic tundra: Heidelberg, Springer-Verlag, p. 73-108.

Washburn, A.L., 1980, Geocryology: New York, John Wiley \& Sons (Halsted Press), 406 p. 


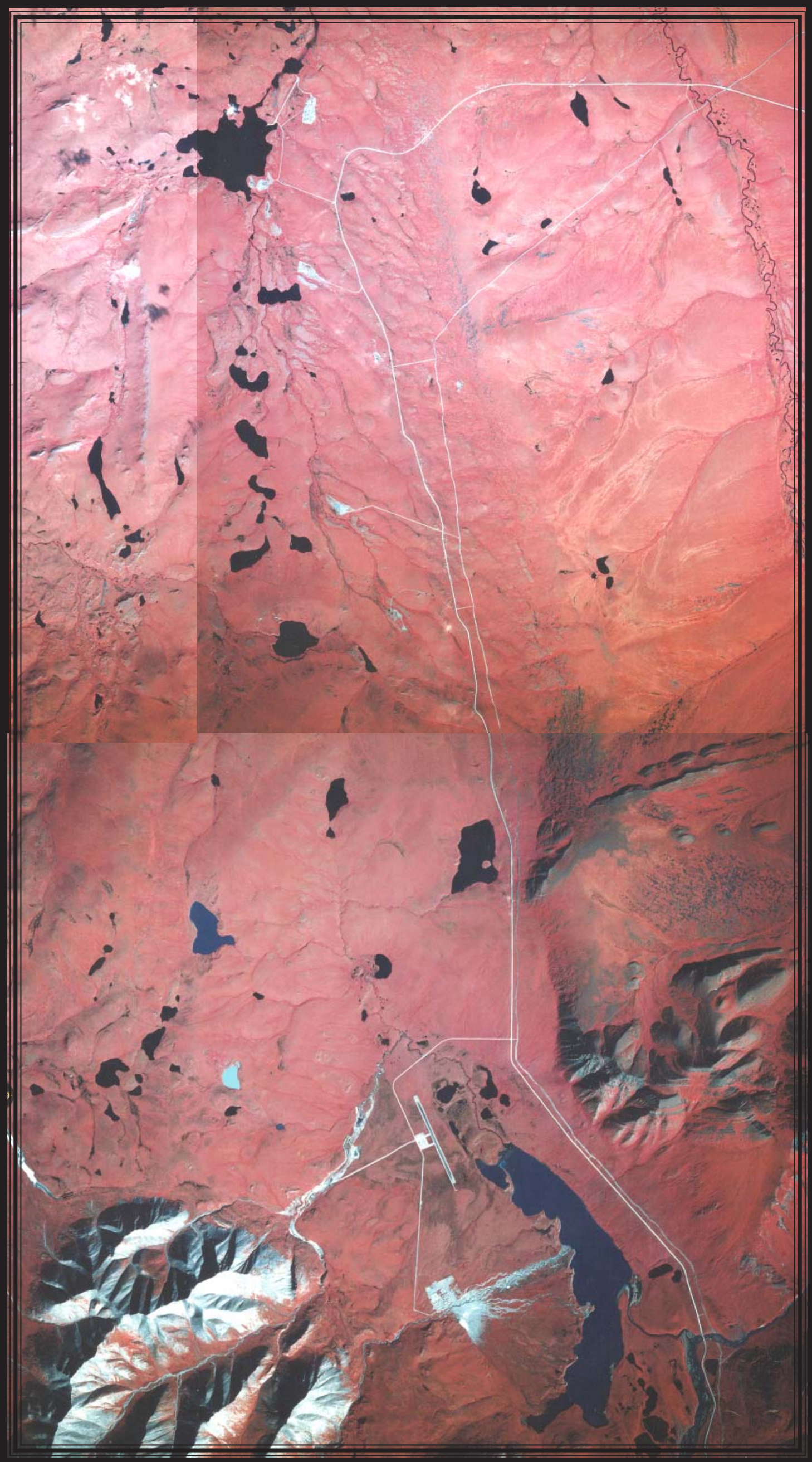

